\title{
DNA barcoding facilitates associations and diagnoses for Trichoptera larvae of the Churchill (Manitoba, Canada) area
}

\author{
David E Ruiter ${ }^{1}$, Elizabeth E Boyle ${ }^{2}$ and Xin Zhou $^{3 *}$
}

\begin{abstract}
Background: The North American Trichoptera larvae are poorly known at the species level, despite their importance in the understanding of freshwater fauna and critical use in biomonitoring. This study focused on morphological diagnoses for larvae occurring in the Churchill, Manitoba area, representing the largest larval association effort for the caddisflies at any given locality thus far. The current DNA barcode reference library of Trichoptera (available on the Barcode of Life Data Systems) was utilized to provide larval-adult associations.
\end{abstract}

Results: The present study collected an additional 23 new species records for the Churchill area, increasing the total Trichoptera richness to 91 species. We were able to associate 62 larval taxa, comprising $68.1 \%$ of the Churchill area Trichoptera taxa. This endeavor to identify immature life stage for the caddisflies enabled the development of morphological diagnoses, production of photographs and an appropriate taxonomic key to facilitate larval species analyses in the area.

Conclusions: The use of DNA for associations of unknown larvae with known adults proved rapid and successful. This method should accelerate the state-of-knowledge for North American Trichoptera larvae as well as other taxonomic lineages. The morphological analysis should be useful for determination of material from the Churchill area.

Keywords: Caddisfly, Freshwater, Life history, Ecology, Biomonitoring, DNA taxonomy, DNA barcoding, Barcoding biotas

\section{Background}

Trichoptera (caddisflies) are a diverse group of insects composed of approximately 13,000 described species worldwide from 45 extant families [1]. This diversity, in part, is thought to be attributed to the ecological variation of their aquatic larvae. Trichoptera larvae display a wide-range of ecological diversity by exploiting a variety of habitat types and occupying various trophic levels by temporally differentiating as well as employing different life strategies [2]. This aquatic larval stage is also sensitive to environmental stressors, such as pesticides, nutrients, and sediments $[3,4]$. As such, Trichoptera larvae are commonly used for biomonitoring of freshwater

\footnotetext{
* Correspondence: xinzhou@genomics.cn

${ }^{3}$ BGI-Shenzhen, Beishan Rd., Yantian District, Shenzhen, Guangdong Province 518083, China

Full list of author information is available at the end of the article
}

habitats as general indicators of water quality and habitat.

However, the utility of these approaches has been impeded by the inability to correctly identify Trichoptera larvae with a high level of taxonomic resolution. This problem is due to the majority of the North American taxonomic literature for Trichoptera being written for adults, in addition to the technical challenges involved in conventional larval/adult association approaches, such as laboratory rearing and the metamorphotype approach of collecting mature pupae and associating larval sclerites and developed adult genitalia within [5]. As such, the larvae of the majority of North American Trichoptera species remain unknown.

There appears to be promise for Trichoptera larval identification through the use of DNA barcoding. In Trichoptera, the DNA barcode region - a mitochondrial cytochrome $c$ oxidase subunit I (COI) fragment - is 
commonly employed as it has been found to have a low intraspecific variation and high interspecific divergence, or a barcoding gap, in most caddisfly species tested, which allows for clear species delineation based on genetic clustering [6-9]. This ability to correctly identify a specimen based on its DNA sequence is particularly useful for associating adult and immature stages of Trichoptera [5,10-14]. By matching an inquiry DNA sequence of an immature life stage to that of a morphologically identified adult, a species-level identification for the larva can be supplied [5]. In addition, the association of different life stages can help delimit morphologically vague species boundaries in adults, as was found in Chinese Mexipsyche (Hydropsychidae) species with distinct larval head markings but cryptic adult male genitalia [5], and in the Diplectrona modesta Banks, 1908 complex in North America [15].

However, the ability to reliably identify an immature life stage through a DNA sequence is dependent on a thorough reference library of DNA barcodes. A geographic area that has had substantial effort to compile a reference library is the subarctic region of Churchill, MB, Canada. Churchill is situated on the southern coast of the Hudson Bay, which marks the transition from boreal to tundra ecosystems, and has also been the focus of a collaborative effort to document the biodiversity of the region for a variety of taxonomic groups - the Polar Barcode of Life campaign (www.polarbarcoding.org). This multi-year effort reported 14 Trichoptera families, 32 genera, and 68 species in recent years $[7,8]$, and built a DNA barcode reference library for the area, which can be accessed through the Barcode of Life Data Systems (BOLD, www.boldsystems.org) [16]. The linkage between a reference library of DNA barcodes and morphologically identified adult voucher specimens for Churchill has enabled rapid and reliable association of Trichoptera larvae with their adults for ecological applications.

The aim of this study was to supplement the current BOLD library of Trichoptera and to provide morphological diagnoses, photographs, and an appropriate taxonomic key for the Trichoptera larvae of the Churchill area. Additional collections and analyses since previous reports $[7,8]$ has resulted in 23 additional taxa being collected from the Churchill area. DNA analysis for this material has resulted in morphological information to allow separation for nearly all of the collected Churchill caddisfly larvae. Development of the taxonomic characters was greatly expedited via use of known DNA associated material.

\section{Results}

An updated checklist for the caddisflies of Churchill Since the first publications on the EPT faunas of Churchill in 2009 and 2010 [7,8], which included only adult sequences, an additional 1,810 caddisfly barcodes have been sequenced (a total of 3,310 COI barcodes being analyzed in the present study), including 148 adults and 1,662 larvae. These new sequences are deposited in BOLD projects: CUTRI, CUTLB, CUTLV, LBTLT, and EBTCH. GPS coordinates and habitat information are publically accessible on BOLD. All COI sequences are available on GenBank under accession numbers: GU680248-GU680333; GU680935-GU681016; GU681233-GU681319; GU711870-GU712502; HM3989 26-HM398969; HM421583; HM909539-HM909550; HQ 944371; HQ962944; HQ986513-HQ986683; JF891300JF891303; JX681817-JX682406; JX682408-JX682522. A total of 91 Trichoptera species (including provisional taxa) are reported in the present paper, including 23 new species records for the Churchill area.

\section{Larval-adult association}

Larvae of 62 species have been collected and associated in this work (Table 1, Figure 1), of which 11 taxa [Ochrotrichia cf. eliaga, Oecetis immobilis (Hagen, 1861), Triaenodes frontalis Banks, 1897, Limnephilus ademus Ross, 1941, L. alaicus (Martynov, 1915), L. indivisus Walker, 1851, L. major (Martynov, 1909), Phanocelia canadensis (Banks, 1924), Neureclipsis valida (Walker, 1852), Polycentropus smithae Denning, 1949, and Rhyacophila mongolica Levanidova, 1993] are represented by only larval specimens. These larvae were assigned to species based on additional barcode references available in BOLD through the Trichoptera Barcode of Life Campaign, using criteria described in the Methods.

\section{Synoptic discussion of Churchill Trichoptera larvae Apataniidae}

Adults of two Apatania species $[$ A. stigmatella (Zetterstedt, 1840) and A. zonella (Zetterstedt, 1840)] have been collected although no larvae were found. Larval descriptions for both taxa are available in Lepneva [17] and Solem [18], although Solem indicated his specimens varied from those of Lepneva. Based on Solem [18], it is possible the Churchill taxa are separable based on the shape of the metanotal sa1 area: $A$. stigmatella with two separate setal areas; A. zonella with a single, contiguous setal area.

\section{Brachycentridae}

Two brachycentrid species, Brachycentrus americanus (Banks, 1899) (Figure 2) and B. fuliginosus Walker, 1852, have been collected in the Churchill area. To date, only larvae of the former species have been collected in the Churchill area. The combination of Flint [19] and Harrington and Morse [20] provide excellent descriptions for all the North American Brachycentrus larvae except $B$. fuliginosus, which remains unknown. 
Table 1 Adult and larval specimens collected from the Churchill area included in this study

Family

Apataniidae

Brachycentridae

\author{
Brachycentridae
}

Glossosomatidae Species

\# Adults

\# Larvae

Apatania stigmatella (Zetterstedt, 1840)

Apatania zonella (Zetterstedt, 1840)

Brachycentrus americanus (Banks, 1899)

Brachycentrus fuliginosus Walker, 1852

Glossosoma intermedium (Klapálek, 1892)

Glossosoma velonum Ross, 1938

Protoptila tenebrosa (Walker, 1852)

\section{Hydropsychidae}

Arctopsyche ladogensis (Kolenati, 1859)

Cheumatopsyche campyla Ross, 1938

Cheumatopsyche ela Denning, 1942

Cheumatopsyche nr. ela

Hydropsyche alhedra Ross, 1939

Hydropsyche alternans (Walker, 1852)

Hydropsyche bronta Ross, 1938

Hydropsyche vexa Ross, 1938

Hydroptilidae

Hydroptila consimilis Morton, 1905

Hydroptila spatulata Morton, 1905

Ochrotrichia cf. eliaga

Oxyethira XZ sp. CHU1

Oxyethira coercens Morton, 1905

Lepidostomatidae

Lepidostoma togatum (Hagen, 1861)

Leptoceridae

Ceraclea annulicornis (Stephens, 1836)

Ceraclea arielles (Denning, 1942)

Ceraclea erratica (Milne, 1936)

Ceraclea excisa (Morton, 1904)

Ceraclea nigronervosa (Retzius, 1783)

Ceraclea resurgens (Walker, 1852)

Mystacides interjecta (Banks, 1914)

Mystacides sepulchralis (Walker, 1852)

Oecetis cf. inconspicua CHU1

Oecetis cf. inconspicua CHU2

Oecetis cf. ochracea CHU1

Oecetis cf. ochracea CHU2

Oecetis immobilis (Hagen, 1861)

Triaenodes frontalis Banks, 1907

Triaenodes reuteri McLachlan, 1880

$\begin{array}{ll}2 & 0 \\ 1 & 0\end{array}$

0
0

3

68

11

0

15

12

34

8

0

0

$12 \quad 6$

$7 \quad 0$

20

40

1

103

2

1

39

1

0

1

5

29

17

45 0

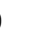


Table 1 Adult and larval specimens collected from the Churchill area included in this study (Continued)

Anabolia bimaculata (Walker, 1852)

Arctopora pulchella (Banks, 1908)

Asynarchus lapponicus (Zetterstedt, 1840)

Asynarchus montanus (Banks, 1907)

Asynarchus mutatus (Hagen, 1861)

Asynarchus rossi (Leonard \& Leonard, 1949)

Grammotaulius interrogationis (Zetterstedt, 1840)

Hesperophylax designatus (Walker, 1852)

Lenarchus fautini (Denning, 1949)

Limnephilus ademus Ross, 1941

Limnephilus alaicus (Martynov, 1915)

Limnephilus argenteus Banks, 1914

Limnephilus canadensis Banks, 1908

Limnephilus dispar McLachlan, 1875

Limnephilus externus Hagen, 1861

Limnephilus extractus Walker, 1852

Limnephilus femoralis Kirby, 1837

Limnephilus fischeri Ruiter, 1995

Limnephilus hageni Banks, 1930

Limnephilus indivisus Walker, 1852

Limnephilus infernalis (Banks, 1914)

Limnephilus kennicotti Banks, 1920

Limnephilus major (Martynov, 1909)

Limnephilus moestus Banks, 1908

Limnephilus nigriceps (Zetterstedt, 1840)

Limnephilus ornatus Banks, 1897

Limnephilus partitus Walker, 1852

Limnephilus parvulus (Banks, 1905)

Limnephilus perpusillus Walker, 1852

Limnephilus picturatus McLachlan, 1875

Limnephilus rhombicus Linnaeus, 1758

Limnephilus sansoni Banks, 1918

Limnephilus sericeus (Say, 1824)

* Nemotaulius hostilis (Hagen, 1873)

Onocosmoecus unicolor (Banks, 1897)

Phanocelia canadensis (Banks, 1924)

Philarctus bergrothi McLachlan, 1880

Molannidae

Philopotamidae 
Table 1 Adult and larval specimens collected from the Churchill area included in this study (Continued)

\begin{tabular}{|c|c|c|c|c|}
\hline & * & Agrypnia glacialis Hagen, 1873 & 4 & 1 \\
\hline & & Agrypnia improba (Hagen, 1873) & 7 & 3 \\
\hline & & Agrypnia macdunnoughi (Milne, 1931) & 14 & 0 \\
\hline & & Agrypnia obsoleta (Hagen, 1864) & 1 & 0 \\
\hline & * & Agrypnia pagetana Curtis, 1835 & 13 & 45 \\
\hline & & Agrypnia straminea Hagen, 1873 & 35 & 30 \\
\hline & & Banksiola crotchi Banks, 1943 & 21 & 1 \\
\hline & & Phryganea cinerea Walker, 1852 & 9 & 0 \\
\hline & & Ptilostomis semifasciata (Say, 1828) & 6 & 0 \\
\hline \multicolumn{5}{|c|}{ Polycentropodidae } \\
\hline & & Neureclipsis crepuscularis (Walker, 1852) & 4 & 7 \\
\hline & * & Neureclipsis valida (Walker, 1852) & 0 & 3 \\
\hline & & Polycentropus aureolus (Banks, 1930) & 4 & 17 \\
\hline & * & Polycentropus smithae Denning, 1949 & 0 & 1 \\
\hline \multicolumn{5}{|l|}{ Psychomyiidae } \\
\hline & & Psychomyia flavida Hagen, 1861 & 4 & 0 \\
\hline \multicolumn{5}{|l|}{ Rhyacophilidae } \\
\hline & & Rhyacophila angelita Banks, 1911 & 41 & 20 \\
\hline & * & Rhyacophila mongolica Schmid, Arefina \& Levanidova, 1993 & 0 & 1 \\
\hline Trichoptera Total & & & 1644 & 1666 \\
\hline
\end{tabular}

New records indicated with an asterisk (*)

In the Churchill area, Brachycentrus larvae are readily identified based on the case, which is usually square, although several Churchill area collections have cases that are partially round and composed of silk (Figure 2C). While the larva of B. fuliginosus is currently unknown, Flint [19] placed B. fuliginosus in the subgenus Sphinctogaster and $B$. americanus in the subgenus Brachycentrus based on adult characters. Flint also provided a hindfemur setal character to separate the two subgenera: the dorsal hindfemoral setae of Brachycentrus are limited to two strong setae while those of Sphinctogaster are more abundant and weaker. Sphinctogaster should also have two pairs of setae located on the venter of the first abdominal segment. A single pair occurs in B. americanus.

\section{Glossosomatidae}

While three glossosomatid taxa have been collected as adults (Table 1) in the Churchill area, only larvae of Glossosoma intermedium (Kapalek, 1892) were associated via their DNA sequences (see figures below for Glossosoma intermedium, lateral). Wiggins [21] provides characters to separate the Glossosoma from the Protoptila, however we are unaware of larval morphological characters to separate the North American species of Glossosoma or Protoptila.

\section{Hydropsychidae}

Eight hydropsychids have been found in the Churchill area, including the Cheumatopsyche campyla Ross, 1938 complex, which may be represented by 3 cryptic lineages (C. campyla, C. ela Denning, 1942, and C. nr. ela), for which larvae are unavailable. Larvae of 4 hydropsychid species have been associated (Table 1, Figure 3).

Arctopsyche ladogensis (Kolenati, 1859) larvae have a pale midline stripe continuing from the head to the thorax (Figure 3A). The head is long relative to Hydropsyche and the anterior margin of the frontoclypeus is convex rather than squared off as in Hydropsyche.

The head patterns of the Churchill area Hydropsyche are fairly distinctive. However, these larval characters have been shown to be highly variable within Hydropsyche species [22,23]. This is also evident in Churchill specimens (Figure 3B-C). Schefter and Wiggins [23] provided morphological characters for separation of the three known Churchill Hydropsyche species, which should be examined if additional color variations are found.

Hydropsyche alternans (Walker, 1852) has the checkerboard head pattern, although based on the two Churchill specimens it can appear quite different between light and dark specimens. $H$. alternans can be 


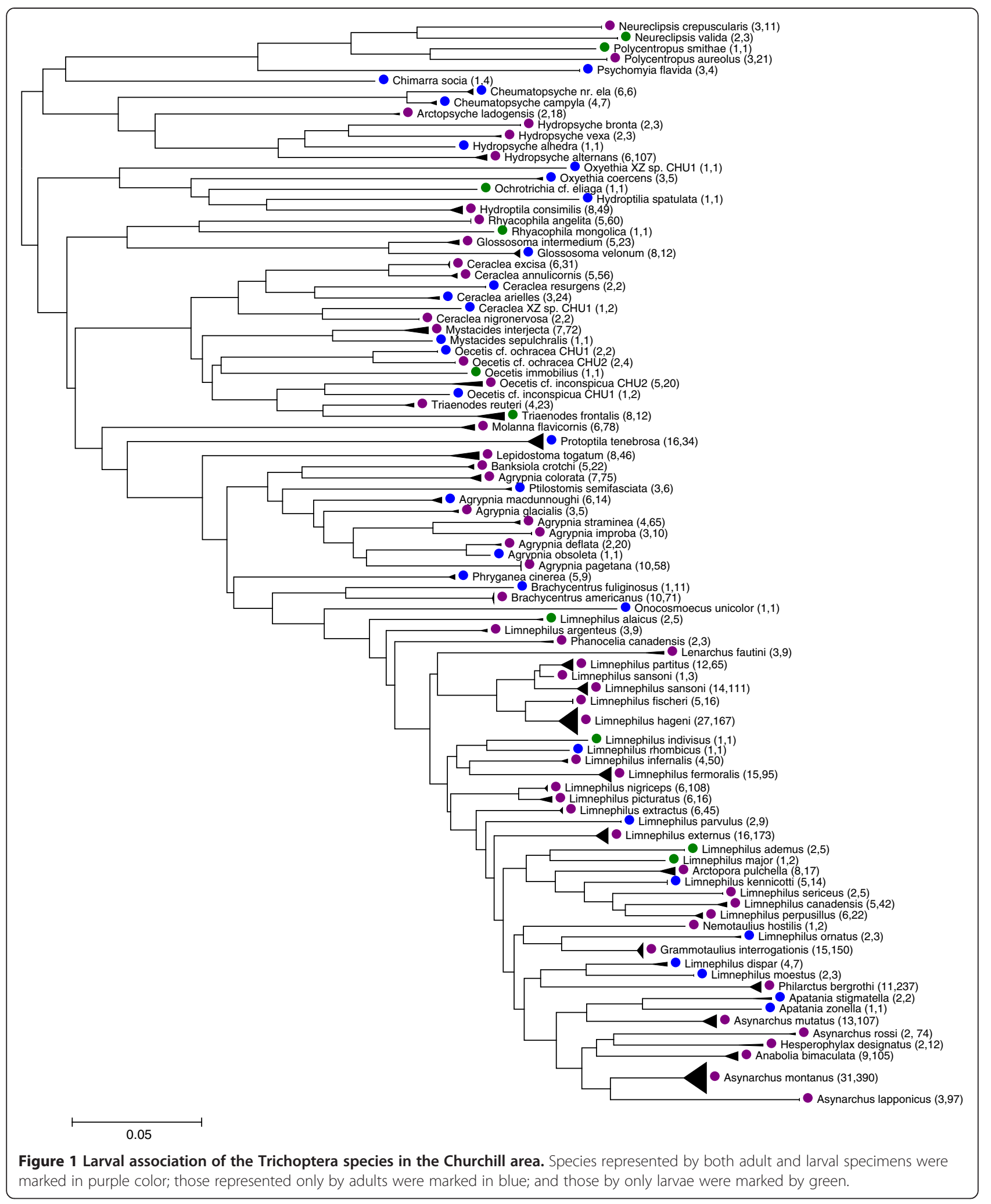



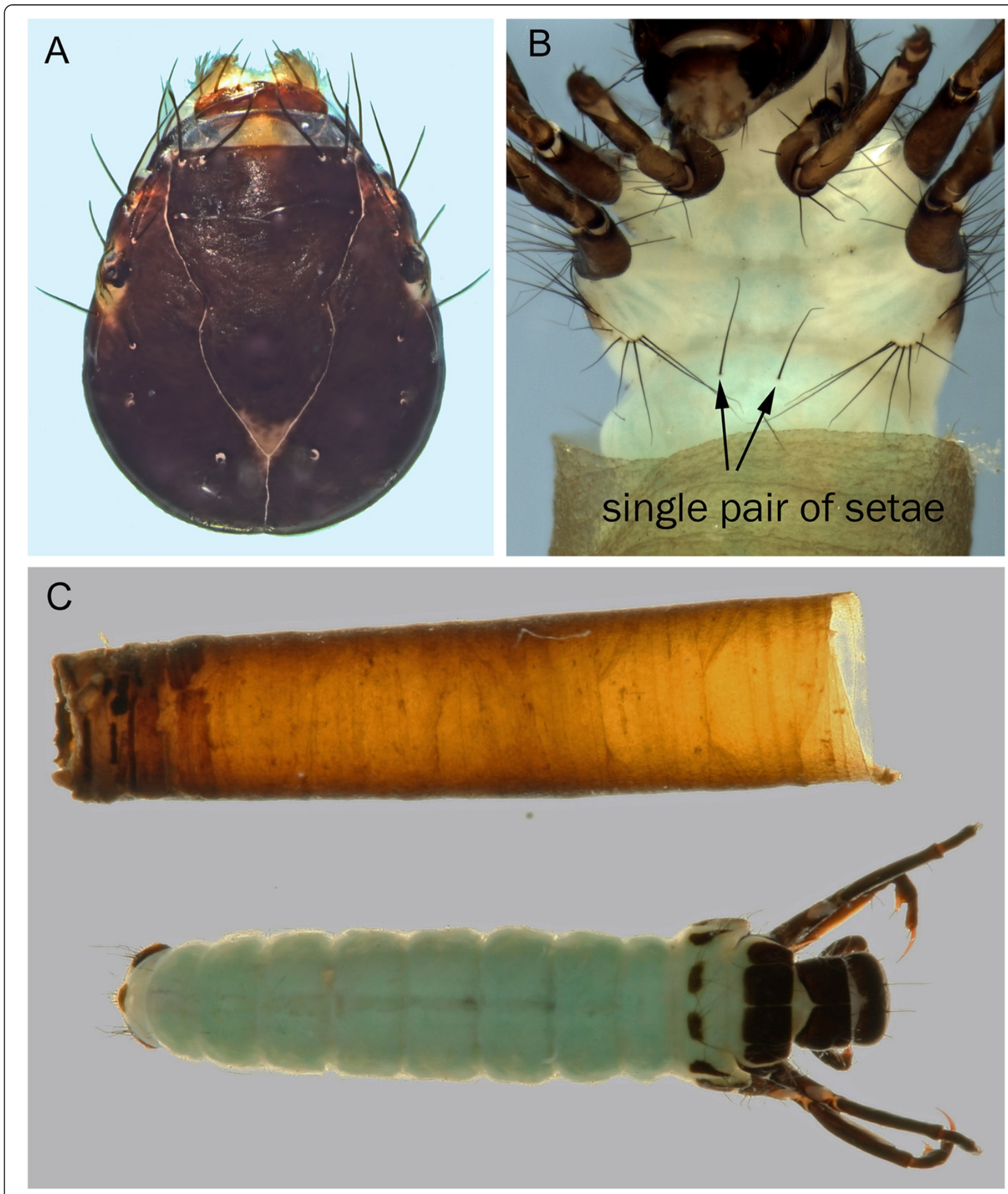

Figure 2 Brachycentrus americanus A: head, dorsal; B: abdomen, ventral; C: habitus and case, dorsal. 

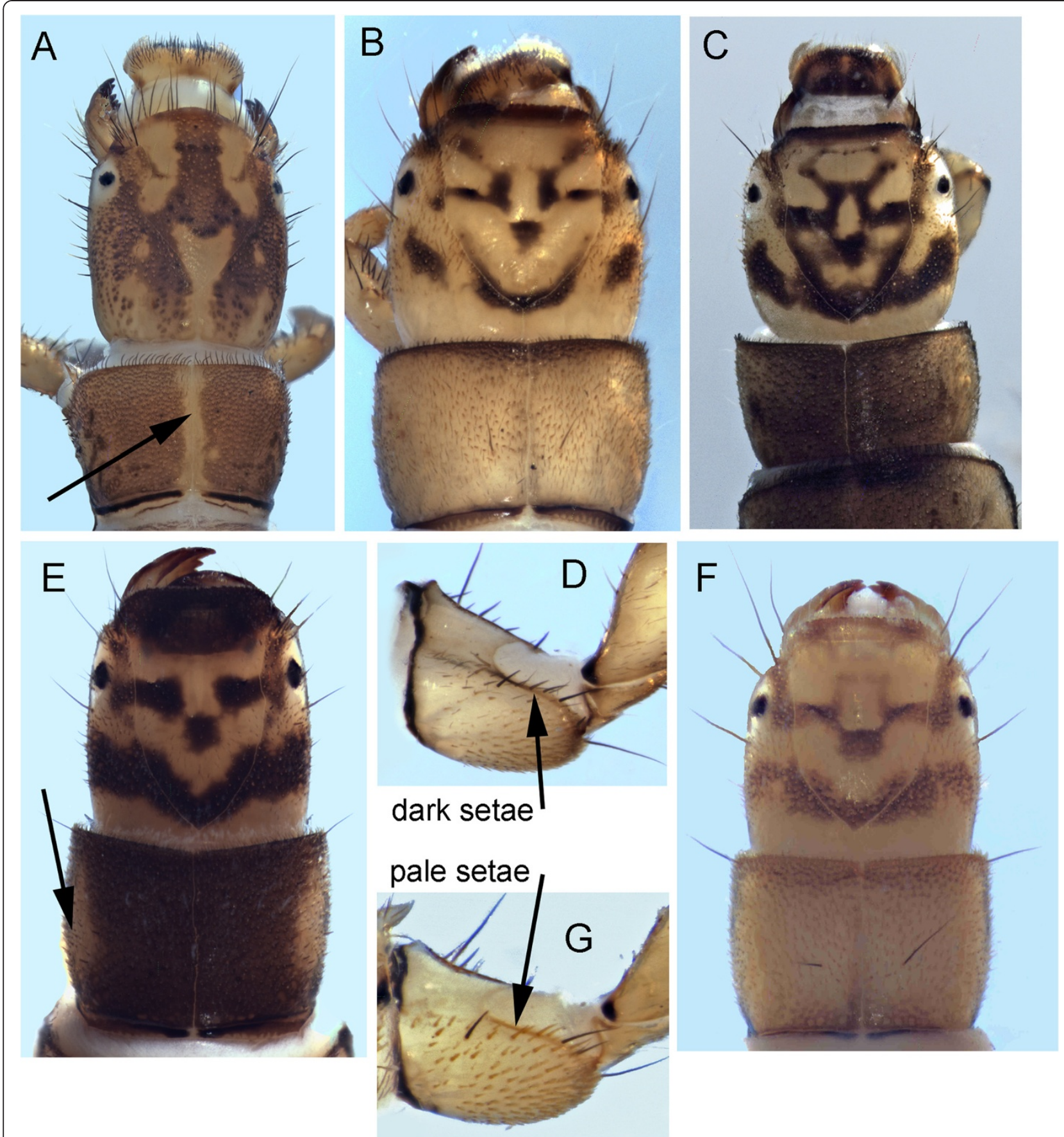

Figure 3 Arctopsyche ladogensis A: head, dorsal; Hydropsyche alternans B \& C: color variation, dorsal, D: procoxa; Hydropsyche bronto $\mathrm{E}:$ head, dorsal; Hydropsyche vexa F: head dorsal, G: procoxa.

separated from $H$. vexa Ross, 1938 by the presence of dark setae along the dorsal margin of the procoxal outer surface (Figure 3D).

H. bronta Ross, 1938 larvae (based on a single Churchill specimen) have a two-toned pronotum (Figure 3E), which is pale laterally and darkened dorsally. This character is distinct from the other two known Churchill area Hydropsyche.
The pronotum of $H$. vexa is pale yellow without obvious markings other than the anterior and posterior darkening evident on some specimens (Figure 3F). The head has a checkerboard pattern. It can be separated from $H$. alternans by the presence of pale setae along the dorsal margin of the procoxal outer surface (Figure 3G). 
Lepneva [24] provided a detailed description of the Arctopsyche ladogensis larvae. Schuster and Etnier [22] provided a description for $H$. bronta and Schefter and Wiggins [23] described all four Churchill area Hydropsyche larvae, although we did not collect larval $H$. alhedra.

\section{Hydroptilidae}

Of the five hydroptilid taxa collected in the Churchill area (Table 1), only 2 larvae [Hydroptila consimilis Morton, 1905 and Ochrotricha cf. eliaga (a single specimen)] have been collected. These two genera have very similar larvae [21] and, in the Churchill specimens, can be most readily separated by the presence of a dark, elongated, anteroventral lobe on the mesonotum in Ochrotrichia, which is lacking in Hydroptila (Figure 4). Other characters to separate larvae of these two genera are also available [21]. We are unaware of larval descriptions for these two species.

\section{Lepidostomatidae}

A single species of Lepidostoma [L. togatum (Hagen, 1861)] has been collected in the Churchill area. Weaver [25] pointed out that L. togatum is one of the most wide ranging Lepidostoma in North America and the panel-cased larvae
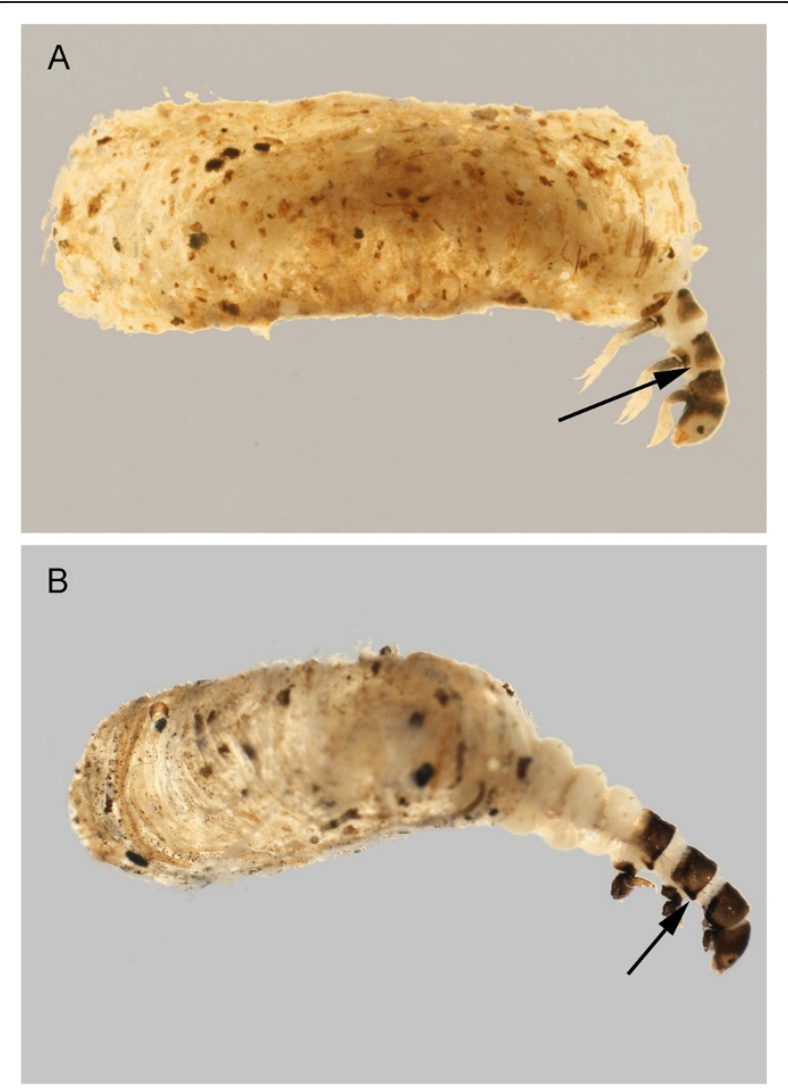

Figure 4 Hydroptila consimilis A: lateral; Ochrotrichia cf. eliaga B: lateral. inhabit both lotic and lentic habitats. In the Churchill area, this species is primarily lotic and its case is composed of fine mineral grains arranged in a smooth, tapered, slightly curved manner (Figure 5). The dorsum of the head has pale muscle scars on a darker background, typical of many Lepidostoma. The venter of the head is much darker anteriorly than the dorsum, with a few pale, linear muscle scars posterolaterally.

\section{Leptoceridae}

Based on morphological examination and barcode analysis, 15 leptocerid taxa have been collected in the Churchill area (Table 1, Figures 1). Oecetis inconspicua (Walker, 1852) and O. ochracea Curtis, 1825 each forms two distinct COI clusters, which are supported by genitalic morphological features [8]. Larvae of only 1 of each of these species pairs were collected and examined in this study. Provisional taxon codes from Zhou et al. [8] are followed here.

The 9 larval leptocerid taxa associated via DNA from the Churchill area include: Ceraclea annulicornis (Stephens, 1836), C. excisa (Morton, 1904), C. nigronervosa (Retzius, 1783) (1 specimen), Mystacides interjecta (Banks, 1914), Oecetis immobilis (1 specimen), O. cf. inconspicua CHU1 (1 specimen), O. cf. ochracea CHU2 (1 specimen), Triaenodes frontalis, and T. reuteri McLachlan, 1880. A combination of larval head coloration and setation can be used to separate all 9 taxa.

The three Churchill Ceraclea larvae that were associated by $\mathrm{COI}$ (C. annulicornis, $C$. excisa, $C$. nigronervosa) can be separated by a combination of head coloration and $9^{\text {th }}$ tergite setation (Figure 6). Resh [26] provided life histories and descriptions for 23 North American species and included all but C. erratica from the Churchill Ceraclea taxa.

Ceraclea annulicornis can be distinguished from the other known Churchill Ceraclea by the combination of the dark frontoclypeal area with pale muscle scars and a single pair of long setae on the $9^{\text {th }}$ tergite (Figures 6A\&C). The case is made of small mineral grains with the dorsal anterior margin extended and curved downward over the anterior entrance.

Ceraclea excisa has the single pair of long setae on the $9^{\text {th }}$ tergite like C. annulicornis. It can be distinguished from the latter by the dark muscle scars on the dark frontoclypeus (Figures 6D\&F). The mineral case is more narrowly tapered than that of C. annulicornis and the dorsal anterior area only slightly overhangs the case opening.

Ceraclea nigronervosa can be separated from the other Churchill Ceraclea by the presence of 2 pairs of setae on the $9^{\text {th }}$ tergite (Figure 6I). The frontoclypeus has dark muscle scars on a dark background and the case is comprised primarily of silk with attached detritus. 

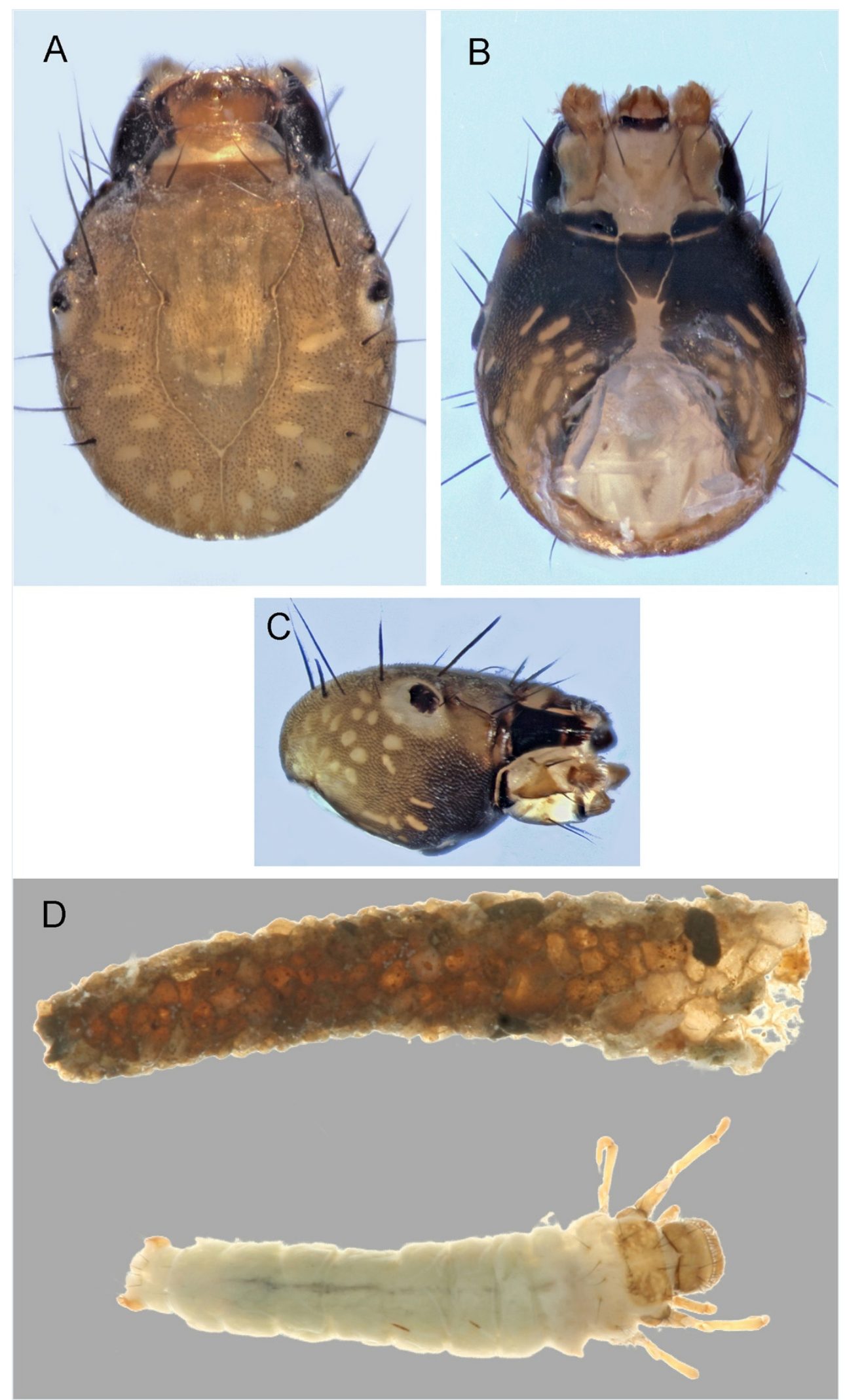

Figure 5 Lepidostoma togatum A: head, dorsal; B: head, ventral; C: head, lateral; D: habitus, dorsal. 

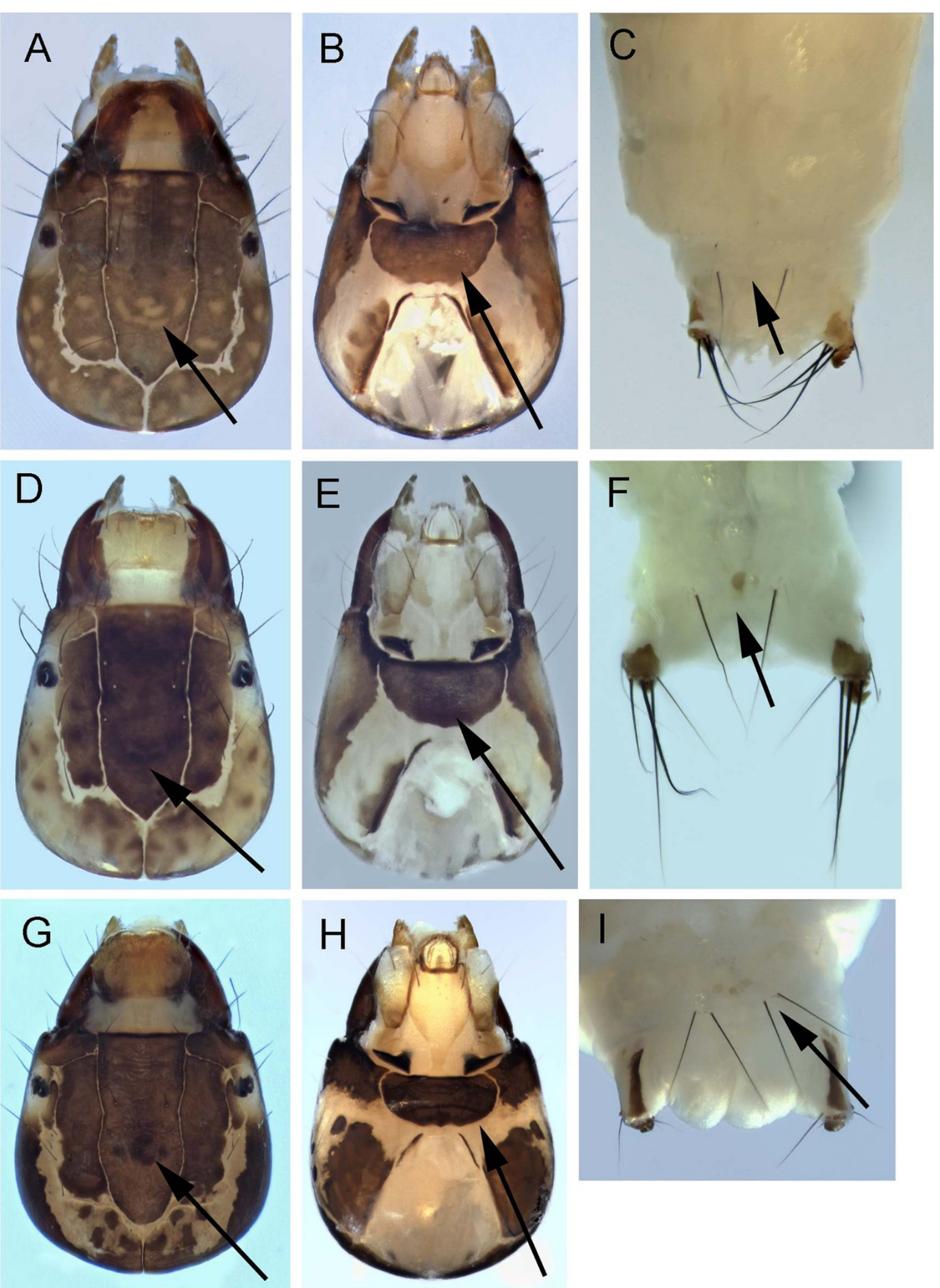

Figure 6 Ceraclea annulicornis A: head dorsal; B: head ventral; C: $9^{\text {th }}$ tergite dorsal; Ceraclea excisa D: head dorsal; E: head ventral; F: $9^{\text {th }}$ tergite dorsal; Ceraclea nigronervosa G: head dorsal; H: head ventral; I: $9^{\text {th }}$ tergite dorsal. 
Larvae of both Churchill Mystacides have been described [27]. M. interjecta has a straight case made of sand grains and small bark particles (see figures below for $M$. interjecta). They lack the large, long, ballast sticks typical of Mystacides, although the head color pattern is the same as portrayed by Yamamoto and Wiggins [27] (Figure 7A). M. sepulchralis (Walker, 1852) larvae were not collected from the Churchill area during this work.

Based on DNA and morphology, possibly five distinct Oecetis species have been collected in the Churchill area [8]. Two distinct genetic lineages of Oecetis cf. inconspicua, two of $O$. cf. ochracea and O. immobilis were collected. Floyd [28] pointed out the difficulty with the morphological separation of Oecetis larvae and the Churchill DNA results support that conclusion. Very few of the Churchill Oecetis larvae were collected: one each for O. immobilis and O. cf. inconspicua CHU1, and only three for $O$. cf. ochracea CHU2.

Oecetis immobilis can be separated from the other known Churchill Oecetis larvae by the combination of pale head background color and a large, dark blotch between the eye and frontoclypeus (Figure 7C). The single Churchill specimen is immature and the colors are not fully developed although it is similar to the figures of Floyd [28].

Oecetis cf. inconspicua CHU1 is very similar to $O$. immobilis but differs in the scattered dark muscle scars arranged along the frontoclypeal suture behind the eye, which are absent in O. immobilis (Figure 7E). These characters are also based on a single immature specimen and do not match any of the suspected O. inconspicua included in Floyd [28].

Oecetis cf. ochracea CHU2 is readily separated from the other known Churchill Oecetis by the dark base color (Figure 7F). It also does not match the description by Floyd [28].

There are two Triaenodes in the Churchill area: $T$. frontalis and $T$. reuteri. They both construct spiral plant cases (see figures for $T$. frontalis and T.reuteri below). The larvae can be separated by the head patterns (Figure 7H\&I). Glover [29] discussed (as Ylodes) several additional unknown larvae related to $T$. frontalis and $T$. reuteri. $T$. frontalis have a pale, medial stripe and no muscle scars on the frontoclypeus. It is similar to the $T$. frontalis description of Glover [29]. T. reuteri has a dark background on the frontoclypeus and numerous, darker muscle scars, which is also similar to the description by Glover [29].

\section{Limnephilidae}

The limnephilids are the most diverse family found in the Churchill area. We have made larval associations for 23 of the 32 taxa. While highly diverse, the larvae of this small collection seem to be distinguishable based on a combination of head color patterns and various setal characters (Figures 8, 9, 10, 15, 16 and 17). Since there are a large number of limnephilid species in the Churchill area, it must be remembered that the discussion below, and the key at the end of this document, is primarily based on only one or two specimens of each species. Usually those specimens were missing at least one leg, and often more from routine barcoding analysis. Not all specimens were in good condition or of the last instar. So the characters presented here should be re-examined in detail when additional material becomes available. We have included observations of case characteristics for several of the species but it should be recognized that Limnephilidae cases, even within a single population, can be very different, and some species rebuild a completely different pupal case in the $5^{\text {th }}$ instar from that of the earlier instars.

Anabolia A single species of this genus, Anabolia bimaculata (Walker, 1852), has been collected. The larval head and thorax have a pale yellow background color with numerous, distinct, dark muscle scars on both head and thoracic segments (Figure 8A); a single mesonotal sa1 seta, and dorsal abdominal chloride epithelia [21]. Anabolia also have a scurf of small, stout spicules on the anterolateral surface of the pronotum which is readily visible at 40X; and, accessory setae on the lateral surfaces of the meso- and metatrochanters and femur. The case, although variable, is always of vegetation. The larva of $A$. bimaculata has been described by Betten [30], Denning [31], and Flint [32].

Arctopora A couple Arctopora pulchella (Banks, 1908) larval specimens were collected in the Churchill area (Figure 8B). The genus could be readily confused with Anabolia and Grammotaulius based on the case. The colors and muscle scars of Arctopora larvae tend to be paler and less distinct than Anabolia (Figure 8A). Arctopora lacks both the scurf of small, stout spicules on the anterolateral surface of the pronotum, and the accessory setae on the mesofemur lateral surfaces typical of Anabolia. Arctopora can be readily separated from Grammotaulius by the short ventral apotome, which does not extend to the posterior margin of the head. The two major ventral femoral spines of all three Arctopora legs are pale. The case is of vegetation and the larva was described (as Lenarchulus) by Flint [32].

Asynarchus Larvae for all 4 species of this genus in the Churchill area have been associated. Their larvae can be separated from other limnephilid genera by a combination of: presence of accessory setae on the mesofemur lateral surface; scurf of small, stout spicules on the 

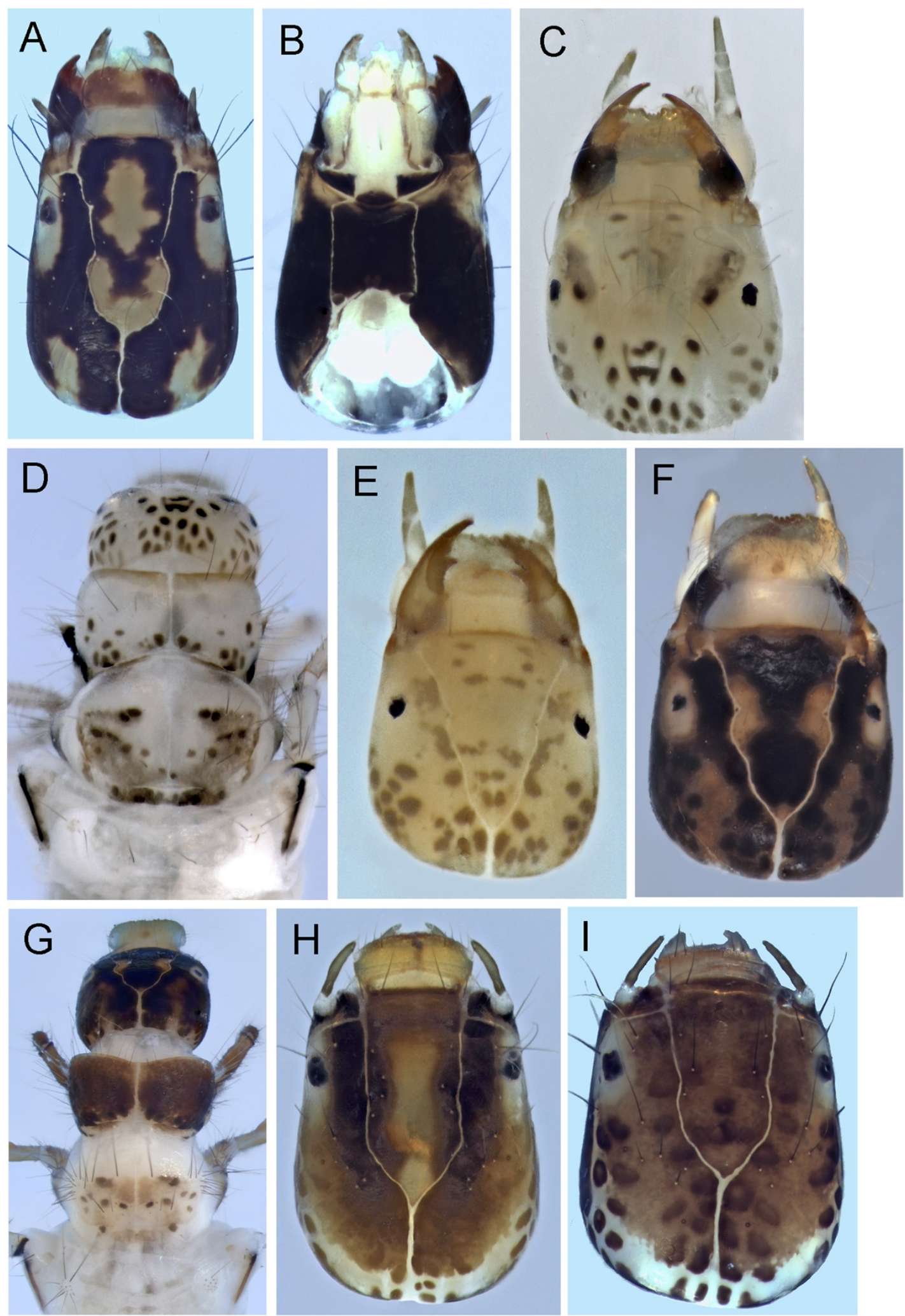

Figure 7 Mystacides interjecta A: head, dorsal; B: head, ventral; Oecetis immobilis C: head, dorsal, D: thorax, dorsal; Oecetis cf. inconspicua CHU1 E: head, dorsal; Oecetis cf. ochracea CHU2 F: head, dorsal; G: thorax, dorsal; Triaenodes frontalis H: head, dorsal; Triaenodes reuteri: I: head, dorsal. 


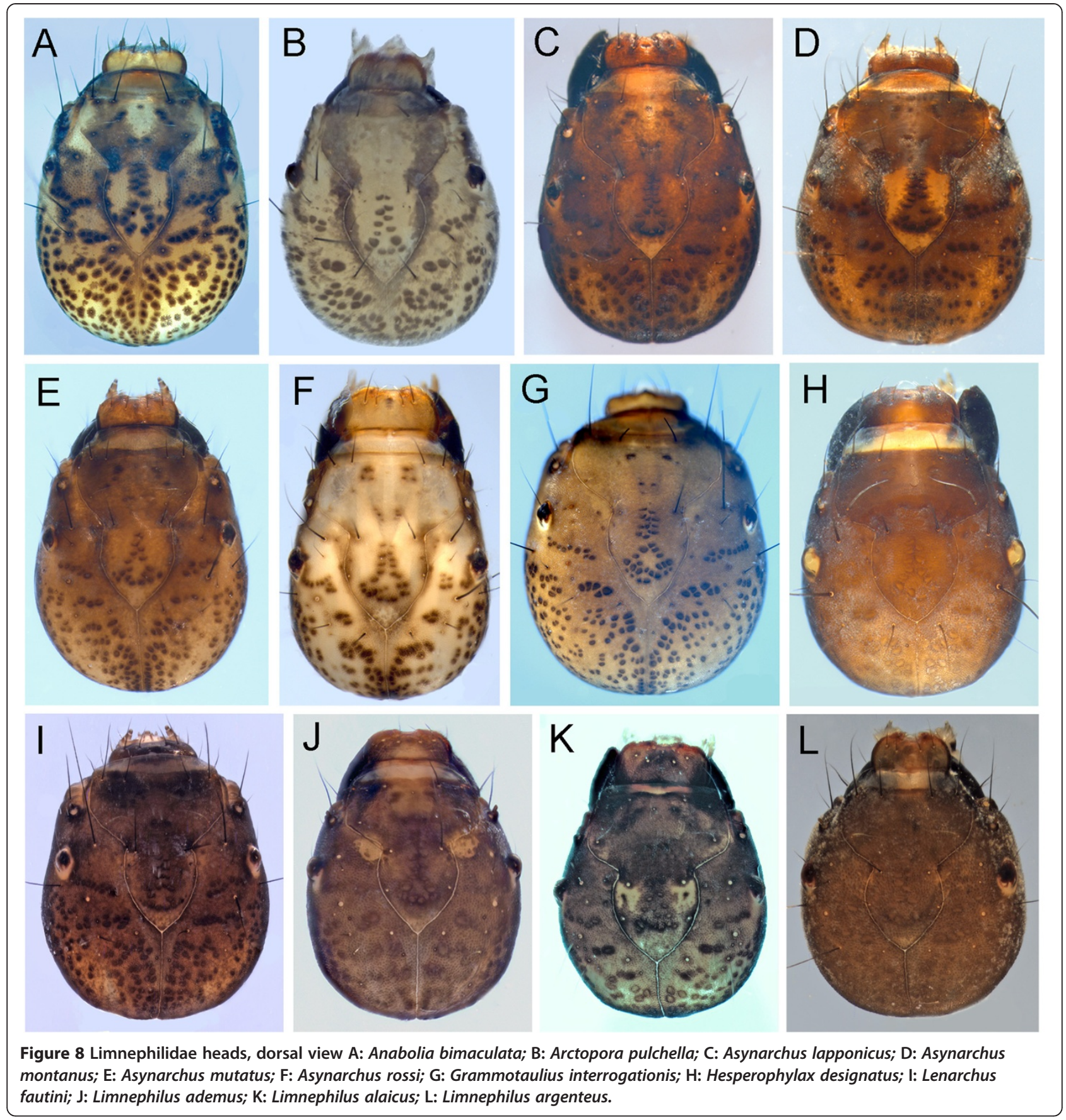

anterolateral surface of the pronotum absent; and [except for A. rossi (Leonard and Leonard, 1949)] presence of dorsal chloride epithelia. The cases tend to be fairly straight and composed of small mineral particles with occasional small vegetal particles. It appears larvae of the Churchill Asynarchus [unlike Asynarchus contumax (McLachlan, 1880) - see Solem [18]] convert their case to at least partial mineral material just prior to pupation (see Wiggins [21]).
Flint [32] also reported vegetal pupal cases for species in this genus.

Asynarchus lapponicus Zetterstedt, 1840 (Figure 8C) is very similar to $A$. montanus (Banks, 1907). Both have accessory setae on the basal trochantal segment. The gill character is based on examination of two $5^{\text {th }}$ instar larvae of both species. The abdominal ventrolateral gill row of $A$. lapponicus ends on the $4^{\text {th }}$ segment. 


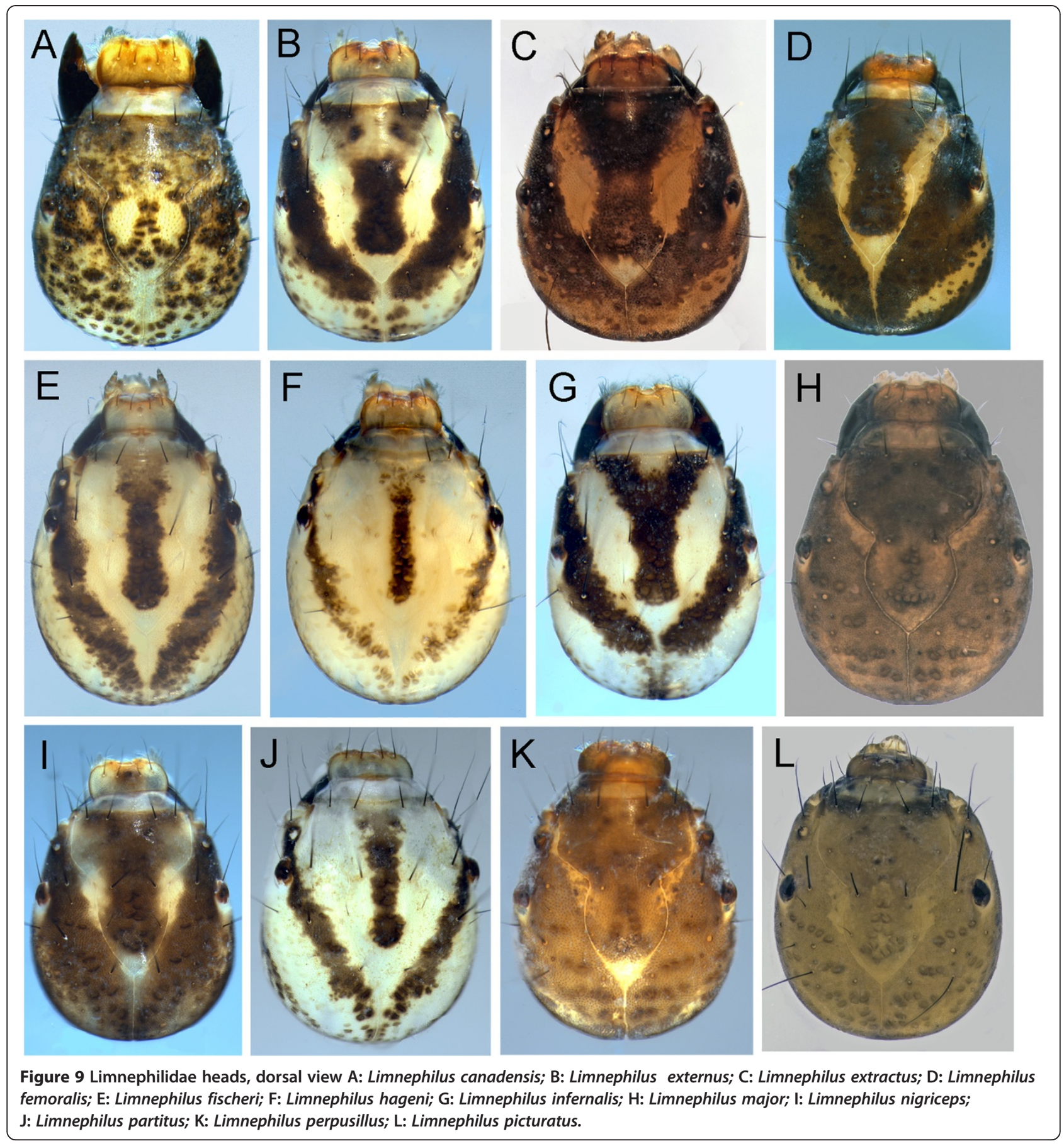

Asynarchus montanus larvae (Figure 8D) are distinguished from A. lapponicus (see discussion above) by the ventrolateral gill row ending on the $6^{\text {th }}$ or $7^{\text {th }}$ abdominal segment.

Asynarchus mutatus (Hagen, 1861) (Figure 8E) can be separated from A. lapponicus and A. montanus by the lack of accessory setae on the basal trochantal segment. Its ventrolateral abdominal gill series also extends to the $6^{\text {th }}$ or $7^{\text {th }}$ segment $(\mathrm{n}=2)$.
Asynarchus rossi has been variously placed in Asynarchus [33,34] and Limnephilus (Leonard and Leonard 1949, Wiggins [21] - with Schmid's concurrence) and presents interesting larval and adult characters. The placement of $A$. rossi on the Neighbor Joining tree was very far from the rest of the Asynarchus species as well as Limnephilus spp., suggesting a generic revision of the species is needed, although the NJ tree should not 


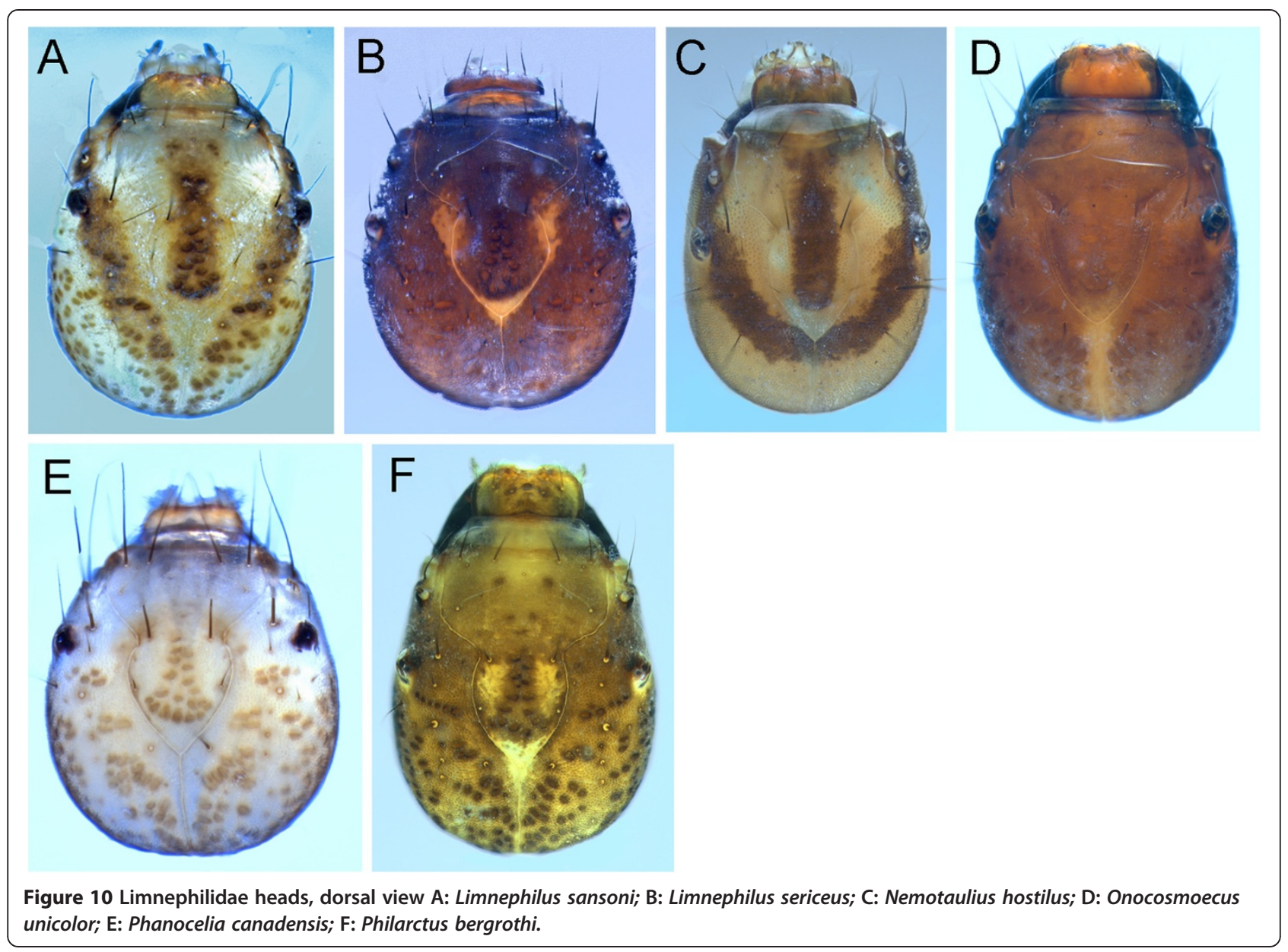

be inferred as a phylogenetic relationship for the relevant species. The distinctiveness of $A$. rossi is also supported by a phylogenetic tree built based on COI and 3 nuclear genes using a Bayesian approach (Boyle, unpublished data). The larvae have several setae on the metanotal membrane between the sa2 sclerites, which are absent in the other Asynarchus, and Limnephilus. Like Limnephilus, A. rossi lacks dorsal chloride epithelia. A. rossi larvae have a very pale yellow head and thorax background color, and, as a result lack the obvious 3-spot frontoclypeus (Figure 8F). In hand, the larvae appear to have a distinct dark, medial thoracic/head stripe. The case is normally comprised of mineral particles and is more curved than that of Asynarchus and Limnephilus.

Grammotaulius As Wiggins [21] pointed out, the larvae of this genus seem to be highly variable. The larvae of the single Churchill species, Grammotaulius interrogationis (Zetterstedt, 1840), are most similar to Arctopora pulchella with base color and muscle scars of Grammotaulius larvae being very pale yellow with numerous dark muscle scars
(Figure 8G). G. interrogationis also lacks the scurf of small, stout spicules on the anterolateral surface of the pronotum; lacks the accessory setae on the mesofemur lateral surfaces and have dorsal chloride epithelia. The case is of vegetation (see Wiggins [21]). Grammotaulius can be distinguished from Arctopora by the long ventral apotome, which reaches the posterior margin of the head. Arctopora is also smaller. When mature, G. interrogationis larvae exceed $25 \mathrm{~mm}$ in length while those of A. pulchella do not exceed $20 \mathrm{~mm}$.

Hesperophylax The only Hesperophylax species collected from the Churchill area is $H$. designatus (Walker, 1852) (Figure $8 \mathrm{H}$ ), and is one of the three Churchill genera (Lenarchus, Onocosmoecus) with more than 3 gill filaments per cluster on some segments. It can be readily separated from Lenarchus and Onocosmoecus by the presence of accessory setae on the mesofemur lateral surfaces and on the metanotal surface between the sa2 sclerites. Flint [32] pointed out that the larvae of this species have probably 
been described more times than any other North American caddisfly species.

Lenarchus We collected one Lenarchus species, L. fautini (Denning, 1949) (Figure 8I), in the Churchill area. The larva has at least some gill clusters with more than six filaments (likely some clusters will have many more than 6 filaments) and usually a vegetation case made of large pieces like Arctopora, Grammotaulius and some Anabolia. Lenarchus fautini lack the setae located on the membrane between the metanotal sa2 sclerites, which are present in Hesperophylax. And at least the anterior gill clusters have many more gill filaments than the maximum of four or so in Onocosmoecus unicolor (Banks, 1897).

Limnephilus Limnephilus larvae currently comprise a large, poorly defined genus. This uncertainty in phylogeny is very apparent in the Churchill Limnephilus larvae. Of the 24 Limnephilus species collected at Churchill, larvae of 18 have been associated via DNA. Over the years, major advancements in our ability to separate the North American Limnephilus sensu lato larvae have been largely limited to those of Lloyd [35], Flint [32] and Hoopes [36]. The most recent work of Wiggins [21,37] has greatly improved our ability to separate the Limnephilus sensu lato larvae from the other limnephilid genera although he pointed out that larvae of only 5 North American Limnephilus species had been described at the time. More frequent advances in Holarctic larval Limnephilus taxonomy have occurred, particularly with the work of Lepneva [17], Hiley [38], Wallace et al. [39] and Waringer \& Graf [40]. The recent Wallace et al. [39] publication provides the best summary available today of characters useful for species determinations.

Limnephilus ademus - The larvae of $L$. ademus belong to the group with both: a dark base colored head with darker muscle scars (Figure 8J); and, accessory setae present on the lateral margins of the meso- and metafemur. The head has two pale blotches primarily outside the anterior constriction of the frontoclypeal suture. A slight pale area is also present in the posterior apex of the frontoclypeal suture. It is most similar to $L$. major, another member of the L. incisus group. The larva was described by Flint and Giberson [41] although the figure of the head presented there does not show the pale areas anterior of the eyes shown here, which occurs in the Churchill larvae.

Limnephilus alaicus - The larvae of L. alaicus is another of the group with accessory setae on the lateral margins of the meso- and metafemur. It can be separated from the closely related $L$. incisus group larva by the anterior pale areas of the head, which are primarily located within the frontoclypeal sutures (Figure 8K). Grigorenko [42] synonymized L. alaicus, L. pallens (Banks, 1920) (a North American species), and L. tricalcaratus (Mosely, 1936) under L. samoedus (McLachlan, 1880). Malicky [43] resurrected $L$. alaicus. It will take further DNA and morphological studies of all taxa within the group to determine which species are valid.

Limnephilus argenteus Banks, 1914 larvae belong to the group of Churchill Limnephilus with the character combination of: head with a dark base color and darker muscle scars (Figure 8L); and, lateral margins of the meso- and metafemur lacking accessory setae. Based on the examined specimens, $L$. argenteus can be separated from the other Churchill larvae in this group $[L$. perpusillus Walker, 1852, L. picturatus McLachlan, 1875, L. sericeus (Say, 1824)] by the very monochromatic brown head coloration with little evidence of pale blotches in the frontoclypeal area.

Limnephilus canadensis Banks, 1908 larvae are relatively small, less than $15 \mathrm{~mm}$ in length. And the cases are made of medium size mineral particles. There are both dark and light large, primary meso- and metafemur ventral setae with the distal one of the pair pale on the mesofemur and the proximal one pale on the metafemur. The head and thorax have a pale yellow background color with many dark muscle scars (Figure 9A).

Limnephilus externus Walker, 1852 has a distinctive prothoracic color pattern with a large dark band along the anterior margin. The head pattern (Figure 9B) is essentially the same as Nemotaulius hostilus Hagen, 1861. The two primary setae along the ventral mesoand metafemur margins are dark. It is very similar to $L$. extractus Walker, 1852 but can be separated by the presence of numerous setae at the mesonotal sal location.

Limnephilus extractus is another taxa with the characteristic three-band head pattern (Figure 9C) and wide dark band along the anterior margin of the pronotum. It has a single seta at the mesonotal sa1 position (see discussion at L. externus).

Limnephilus femoralis (Zetterstedt, 1840) is one of the four Churchill area taxa with the characteristic threeband head pattern (Figure 9D) and wide dark band along the anterior margin of the pronotum. We had only a single larva for examination. The lateral dark head bands extend to the hind margin of the head in $L$. femoralis, while ending before the hind margin in the other taxa.

Limnephilus fischeri Ruiter, 1995 has a very pale yellow head (Figure 9E) and prothoracic background color. The head and pronotum have a pattern similar to others of the $L$. subcentralis group. In the Churchill area, this group has four species (L. fischeri, L. hageni Banks, 1930, L. partitus Walker, 1852, L. sansoni Banks, 1918), which are most easily separated by coloration. The dark 
mesonotal color makes L. fischeri the easiest to separate from the rest. Its case is made of long, thin vegetal pieces that appear almost spiraled as in Mystacides or Phryganea. The venter of the $1^{\text {st }}$ abdominal segment has very few setae.

Limnephilus hageni larvae are very similar to the rest of the L. subcentralis group larvae (see discussion under $L$. fischeri). The indistinct postgenal band (Figure 9F) and pale pronotal base color separate $L$. hageni from the other $L$. subcentralis group larvae. The cases in the group are also very similar, comprised of long vegetal pieces. In the L. hageni larvae we have, the vegetal pieces are wider than those of $L$. fischeri although this probably has no diagnostic significance.

Limnephilus infernalis (Banks, 1914) has a head and pronotal color pattern (Figure 9G) similar to L. externus and L. femoralis. However, L. infernalis has accessory setae on the meso- and metafemur. The dorsoposterior half of the pronotum lacks obvious muscle scars in $L$. infernalis, while these dark muscle scars are obvious in both L. externus and L. femoralis.

Limnephilus major, like the other L. incisus group larva of the Churchill area (see L. ademus discussion above), has a solid brown background color to the head with darker muscle scars and only pale frontoclypeal markings (Figure 9H). It lacks dorsal chloride epithelia. However, it possesses accessory setae on the lateral surfaces of the meso- and metafemur. The case is made of sand grains and seems quite fragile, and readily crushed. On one specimen we looked at the pale frontoclypeal areas were extremely faint.

Limnephilus nigriceps (Zetterstedt, 1840) has a head and thoracic color pattern very similar to the three-banded head with wide anterior dark pronotal band. However, the head bands are nearly coalesced in most specimens to the point the head appears to have a three-spot pattern (Figure 9I). L. nigriceps, along with $L$. infernalis, differ from the other three-banded head taxa by possessing accessory setae on the meso- and metafemur lateral surfaces. The larvae of $L$. indivisus and L. rhombicus (Linnaeus, 1758) also occur in the Churchill area and are expected to have similar coloration and setation as $L$. nigriceps and L. infernalis [21,36,44]. Limnephilus nigriceps lacks dorsal chloride epithelia. In the Churchill area the case is usually made of small, thin bark pieces haphazardly arranged into a slightly triangular cross section.

Limnephilus partitus (Figure 9J) is very similar to $L$. hageni and L. sansoni Banks, 1918. In L. partitus, the muscle scars of the pronotal dorsoposterior area are widely scattered and distinct and there are few setae on the first abdominal segment.

Limnephilus perpusillus is another taxa with a plain brown head with darker muscle scars and very little color pattern (Figure 9K), and no accessory setae on the meso- and metafemur lateral surfaces. There is a small white triangle in the posterior apex of the frontoclypeal suture and two poorly developed anterior pale areas originating at the anterior frontoclypeal constriction and extending along the frontoclypeal suture nearly to the labrum. These anterior pale areas are located primarily laterad of the frontoclypeal suture. This color pattern is very similar to that of $L$. major (see discussion above) and $L$. picturatus. The ventral apotome of $L$. perpusillus is long (unlike L. picturatus) nearly extending to the posterior head margin. The case is made of dark vegetal fragments and is very smooth and round with little taper or curve.

Limnephilus picturatus has a yellow/brown head with darker muscle scars and a small pale band following the frontoclypeal suture from the apex to the frontoclypeal constriction (Figure 9L). The ventral apotome is short, barely half the length of the ventral ecdysial suture. The meso- and metafemur lack setae on their lateral surfaces. The case is made of fairly large vegetal pieces.

Limnephilus sansoni is another one of the L. subcentralis group (see L. fischeri discussion above) with the pale yellow head and typical medial dark band on the frontoclypeus (Figure 10A); dark U-shaped band outside the frontoclypeal suture; and dark band in the transverse pronotal depression. The thoracic setae are greatly reduced in number with the thoracic sa1 and sa 2 reduced to one or two large setae, often just one. The two major setae of the forefemur ventral margin are not both pale, with the black located distally. The case is similar to others of the group, comprised of long vegetal pieces.

Limnephilus sericeus larvae have a dark brown head with faint, darker muscle scars (see L. argenteus discussion above). There are three obvious pale spots on the frontoclypeus (Figure 10B). These anterior pale areas are located primarily outside the frontoclypeal sutures and do not extend anteriorly much past the eye. This color pattern is similar to L. ademus, from which it can be distinguished by the absence of meso- and metafemur accessory setae. The case is made of vegetal parts arranged in a smooth cylinder. The larva was described by Lepneva [17].

Nemotaulius A single Nemotaulius hostilis larval specimen was collected at Churchill. This species can be readily separated from other Churchill caddis larvae by the combination of: distinct head and pronotal coloration similar to the L. subcentralis group with the medial frontoclypeal dark band surrounded by the U-shaped dark band located laterad of the frontoclypeal sutures (Figure 10C); the pronotum with a dark, transverse band about midlength; meso- and metafemur accessory setae present. While the case is usually flattened in immature 
specimens (see Wiggins [21]), the mature case is often round but still made of fairly large vegetal pieces.

Onocosmoecus Onocosmoecus unicolor is the only dicosmoecin collected so far in Churchill and its larva has not been associated in this study. The numerous large, pale setae along the mesofemur ventral margin, along with the medial stripe of the meso- and metathorax readily separate this taxa from all other Churchill limnephilids. We have included a photo of a specimen associated from Montana where it is fairly common (Figure 10D). The case is usually made of small vegetal pieces arranged into a very smooth, slightly curved and tapered case [21]. The larvae were described in Wiggins \& Richardson [45].

Phanocelia Phanocelia canadensis (Figure 10E) is the only limnephilid collected so far in the Churchill area with gill clusters of a single filament. Wiggins [21] provided a description. The larvae are small, about $10 \mathrm{~mm}$, and the case is poorly constructed, tending to fall apart.

Philarctus Wiggins [21] pointed out the difficulty of separating Philarctus bergrothi McLachlan, 1880 larvae [as P. quaeris (Milne, 1935)] from those of Asynarchus, Clistoronia, and some Limnephilus based on head pattern (Figure 10F). It can be separated from Clistoronia (which has not been collected in the Churchill area) by the presence of accessory setae on the mesofemur lateral surfaces (lacking in Clistoronia). Philarctus can be separated from Anabolia and Asynarchus, which the 3-spot head pattern resembles, by the lack of dorsal chloride epithelia (present in Anabolia and Asynarchus). It can be separated from those Limnephilus with mesofemur accessory setae by the presence of accessory setae on the basal mesotrochanter segment in Philarctus. The case is often constructed of mollusks as figured by Wiggins [21], although immature specimens may use small vegetation pieces, switching to mineral or shells prior to pupation.

\section{Molannidae}

Only a single molannid species, Molanna flavicornis Banks, 1914, has been collected in the Churchill area. Wiggins [21] provides diagnostic information for this genus and M. flavicornis is the only known molannid with a stout spur at the base of the anal proleg (Figure 11). This is another widespread northern taxon with occurrence reported from most of Canada, the northern tier of states and extending down the Rockies as far as Colorado.

\section{Philopotamidae}

Chimarra socia Hagen, 1861, the only philopotamid species collected so far in the Churchill area, can be easily

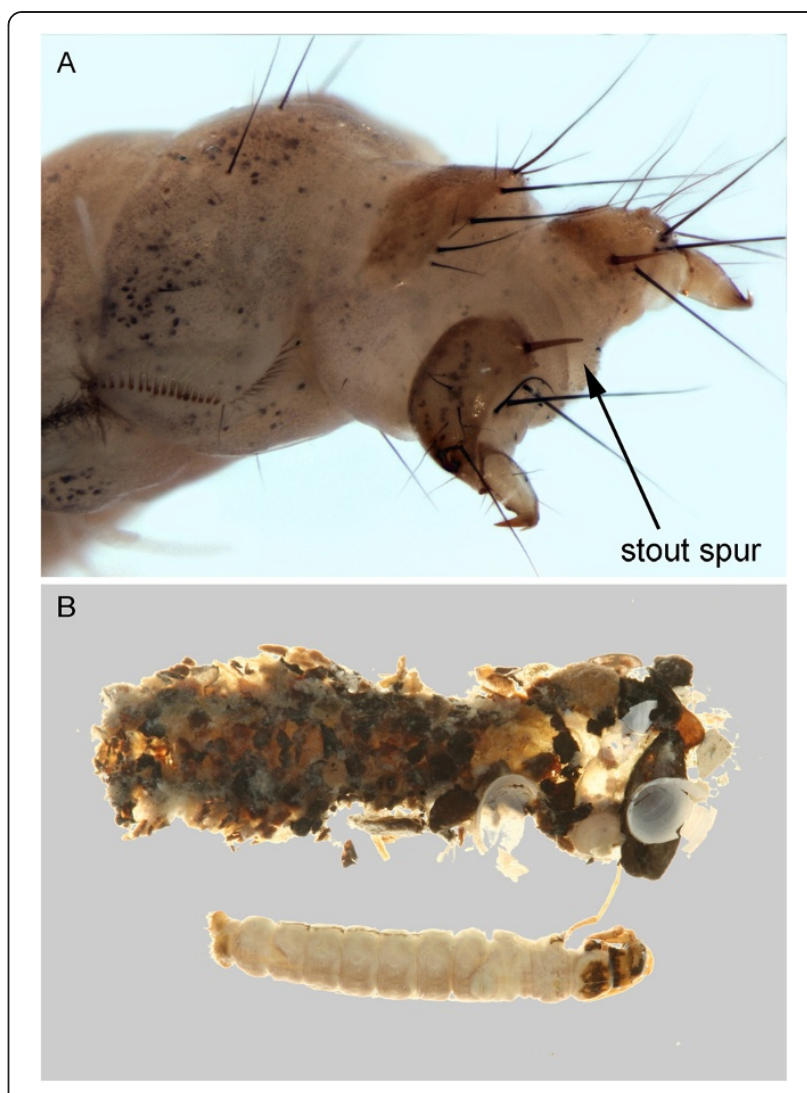

Figure 11 Molanna flavicornis: A: apex of abdomen, oblique; B: habitus, dorsal.

separated from the other Churchill caddis at the family level. Larvae have yet to be collected in the Churchill area.

\section{Phryganeidae}

Larvae for 7 of the 11 Churchill area phryganeids have been associated via COI. The larvae of 3 of the genera [Banksiola crotchi Banks, 1943, Phryganea cinerea Walker, 1852, and Ptilostomis semifasciata (Say, 1828)] can be readily separated at the genus level (see Wiggins $[21,46])$ from the more diverse Churchill Agrypnia.

Agrypnia Agrypnia is the second most diverse caddisfly genus (after Limnephilus) in the Churchill area. Eight of the ten species reported from North America [46] have been collected in the Churchill area and we associated six larvae via COI. While Wiggins [46] indicated the difficulty of using the distinctive head and thorax color to separate the phryganeid genera, the color patterns of the six known Churchill larvae proved useful for separating the Agrypnia species. Comparative pictures of the associated Churchill area larvae are presented in Figure 12.

Agrypnia colorata Hagen, 1873 larvae [along with $A$. deflata (Milne, 1931), A. glacialis Hagen, 1873, and A. 

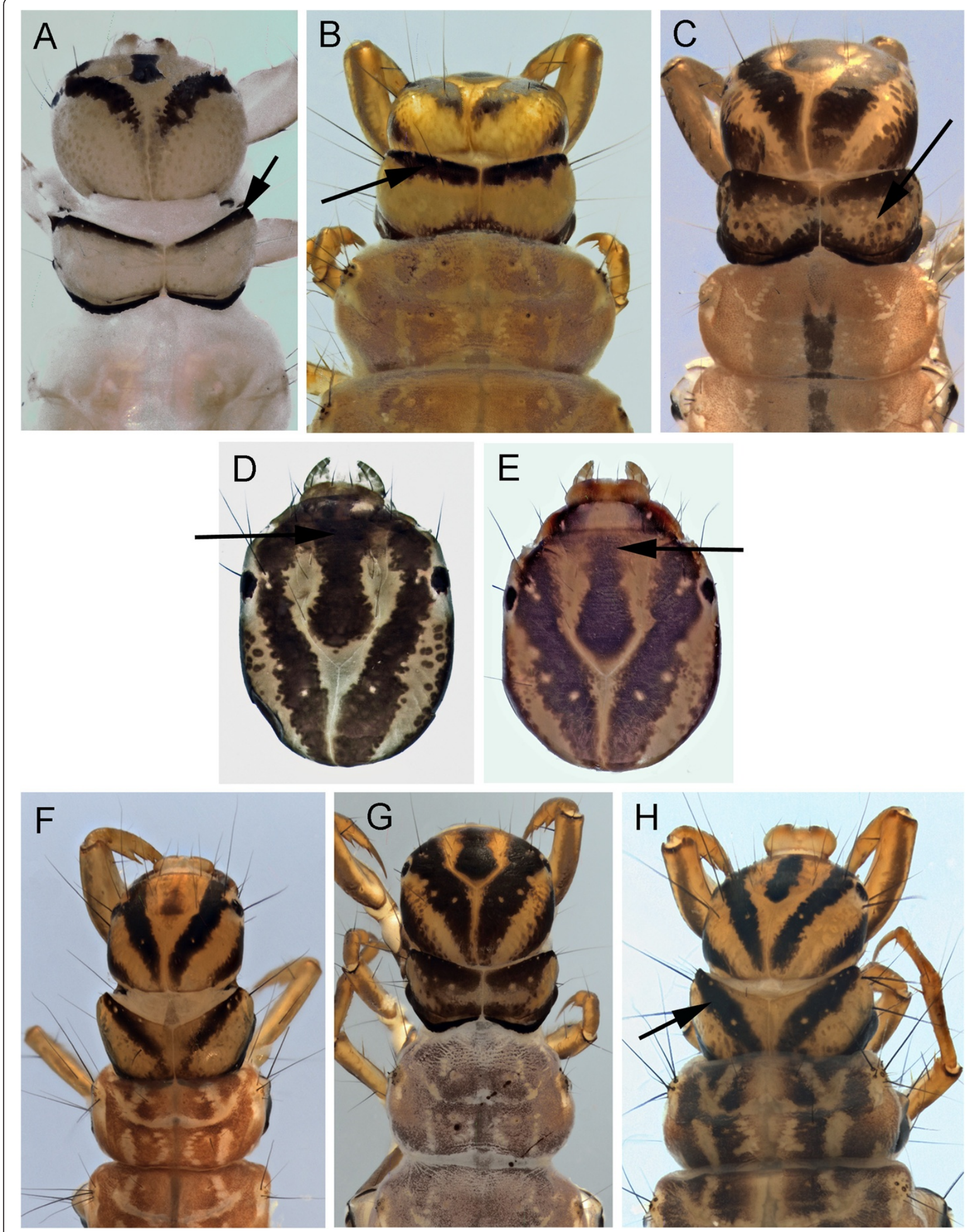

Figure 12 Agrypnia colorata A: dorsal; Agrypnia deflata B: dorsal; Agrypnia glacialis C \& D: dorsal; Agrypnia improba, F: dorsal. Agrypnia pagetana E \& G: dorsal, Agrypnia straminea H: dorsal. 
pagetana Curtis, 1835] belong to a North American group with a dark, transverse band at the anterior and posterior margins of the pronotum (Figure 12A). A. colorata can be separated from the other three by the narrow anterior dark band $v s$. the broad and/or blotchy anterior pronotal bands in the other banded taxa. The two A. colorata larvae examined exhibited color variation on the lateral side of the head that are not evident in the other species. One of the specimens lacked the dark speckling laterally and the dark blotch ventrally. This color variation is likely the result of differences in the age of the specimens and points out the need to use mature specimens for physical characters to separate species.

Agrypnia deflata (Figure 12B) can be separated from the other larvae with banded pronotum by the fairly wide anterior band that lacks the additional dark spotted areas between the anterior and posterior pronotal bands.

Agrypnia glacialis, along with $A$. pagetana, have the anterior pronotal transverse dark band consisting more of a blotch with the anterior band extending towards the posterior band as an area of merged dark spots and blotches (Figure 12C). Only a single DNA associated $A$. glacialis was available for study and it is immature, perhaps a $4^{\text {th }}$ instar based on size. However it clearly exhibits the key hole shaped mesal frontoclypeal band (Figure 12D) of its Eurasian sister species A. picta Kolenati, 1848 (see Wallace et al. [39], Figure 104E). The frontoclypeal medial band does not reach the posterior margin of the frontoclypeus as in $A$. pagetana.

Agrypnia pagetana can be separated from the other known Churchill larvae with transverse bands by the combination of the blotched, dark, anterior pronotal band and the dark mesal frontoclypeal band not expanding at its anterior end (Figure 12E\&G). These characters were also described by Wallace et al. [39]. Unlike A. glacialis, the posterior end of the frontoclypeal medial band in $A$. pagetana reaches the posterior margin of the frontoclypeus. Only a single associated specimen of $A$. pagetana is available for study.

The anterior pronotum of $A$. improba (Hagen, 1873) and $A$. straminea Hagen, 1873 are part of the group which have two diagonal anterior pronotal bands directed posteromesally. These bands appear as a "V" with the apex of the "V" at the posteromesal pronotal margin in dorsal view (Figures $12 \mathrm{~F} \& \mathrm{H}$ ).

Agrypnia improba has a relatively pale, incomplete, medial frontoclypeal band (Figure 12F). This character separates it from A. straminea and Wiggins [46] provides an excellent figure for $A$. improba.

Agrypnia straminea had a distinct, wide, dark medial band on the frontoclypeus (Figure 12H), which separates it from A. improba. A. straminea is also figured by Wiggins [46].

Banksiola A single larva of Banksiola crotchi is associated from the Churchill area. It matches the description and figures provided by Wiggins [46].

Phryganea Larvae for Phryganea cinerea have not been collected during this study. Wiggins [46] provided a description and figure of this species but noted that he could not separate $P$. cinerea from the other associated Phryganea he had available.

Ptilostomis Larvae for Ptilostomis semifasciata have not been collected during this study. Wiggins [46] provided a description and figure of $P$. semifasciata. But, like in Phryganea, he noted that he could not separate $P$. semifasciata from the other associated Ptilostomis he had available.

\section{Polycentropodidae}

Larvae for four Churchill polycentropids have been associated via DNA barcoding. Polycentropus are readily separated from Neureclipsis by the presence of two dark sclerotized bands on the dorsal plate of the anal proleg (Figure 13D), in addition to other characters provided by Wiggins [21].

Neureclipsis crepuscularis (Walker, 1852) has numerous dark muscle scars on the prothorax (Figure 13A), which separates it from $N$. valida (Figure 13B). Wiggins [21] indicated that some Neureclipsis have a pair of short stout setae on the venter of segment nine. These stout setae appear to be a reduction in size of two long setae at this position and are absent in $N$. crepuscularis.

Neureclipsis valida has faint muscle scars on the pronotum (Figure 13B). The stout $9^{\text {th }}$ sternal ventral setae of $N$. bimaculatus (see Wiggins [21]) are also present in $N$. valida (Figure 13C).

Polycentropus aureolus (Banks, 1930) could not be separated from Polycentropus smithae Denning, 1949 based on head coloration. They both have heads with a pale background covered with scattered dark muscle scars (Figure 13E).

\section{Psychomyiidae}

The larvae of the single psychomiid (Psychomyia flavida Hagen, 1861) have not been collected in the Churchill area. However, both Ross [47] and Flint [48] provided descriptions. It can be readily separated from the other Churchill caddisflies by the presence of the large submental sclerites and the hatchet-shaped trochantin (see Wiggins [21]). 

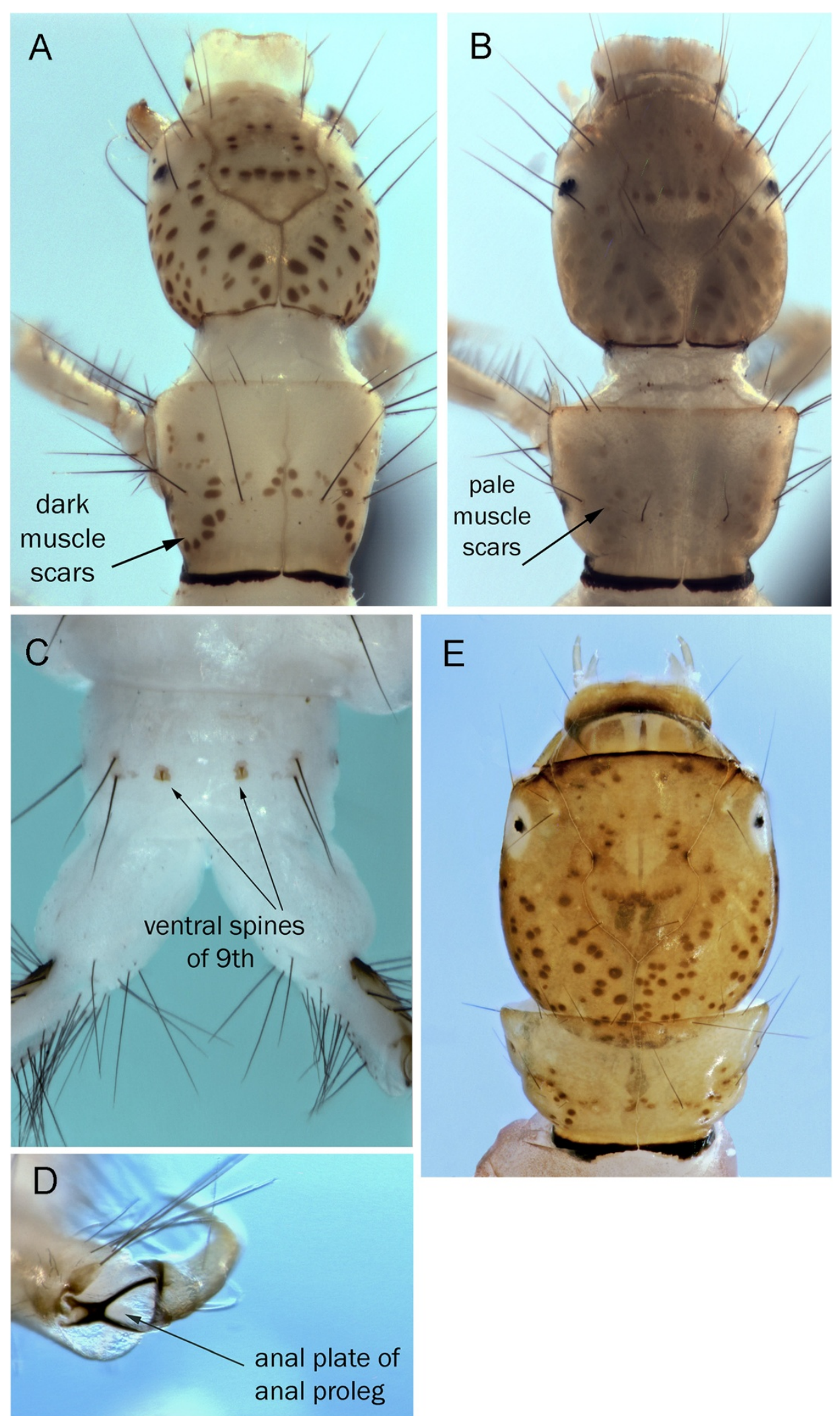

Figure 13 Neureclipsis crepuscularis A: head, dorsal; Neureclipsis valida B: head, dorsal, C: 9th sternite; Polycentropus aureolus D: anal proleg, dorsal, E: head, dorsal. 


\section{Rhyacophilidae}

Larvae of both the Churchill area Rhyacophila ( $R$. angelita Banks, 1911 and R. mongolica) were associated. They can be easily separated by the presence of a curved spike on the lateral sclerite on the anal proleg in R. angelita (Figure 14). The larva of $R$. mongolica is tentatively associated via DNA to adult specimens of the species collected in Mongolia. Wiggins and Parker [49] reported $R$. mongolica adults from the Yukon.

Larval key for Limnephilidae The following key (Table 2) was developed from DNA associated material from the Churchill area. It was only developed for the Limnephilidae as the rest of the fauna was represented by relatively few species, which could be readily separated in the text or at the generic level. It must be recognized that this key may not work as well in other parts of the world. This is particularly true at the species level. While some of the Churchill species were very abundant, larvae of others were rarely collected and the characters below may be based on only a specimen or two.

Most of the characters used below rely on the use of mature larvae, 5th instar, or perhaps 4th. As many characters are based on color patterns, which have proven very consistent in the examined material, these colors will not be as clear in teneral specimens. One other character that has proven very useful is the presence or absence of abdominal dorsal chloride epithelia, which, however, are often difficult to see clearly. Wiggins [21] provided the best approach to observe these characters, i.e., by varying the direction and intensity of the illumination. Lateral illumination often works best. If the chloride epithelia are present, the sclerotized ring surrounding the chloride epithelia can always be found. It is useful to look at the ventral surface before looking at the dorsal surface. That will provide a better estimate of the expected coloration although it seems the dorsal chloride epithelia are always fainter than the ventral.
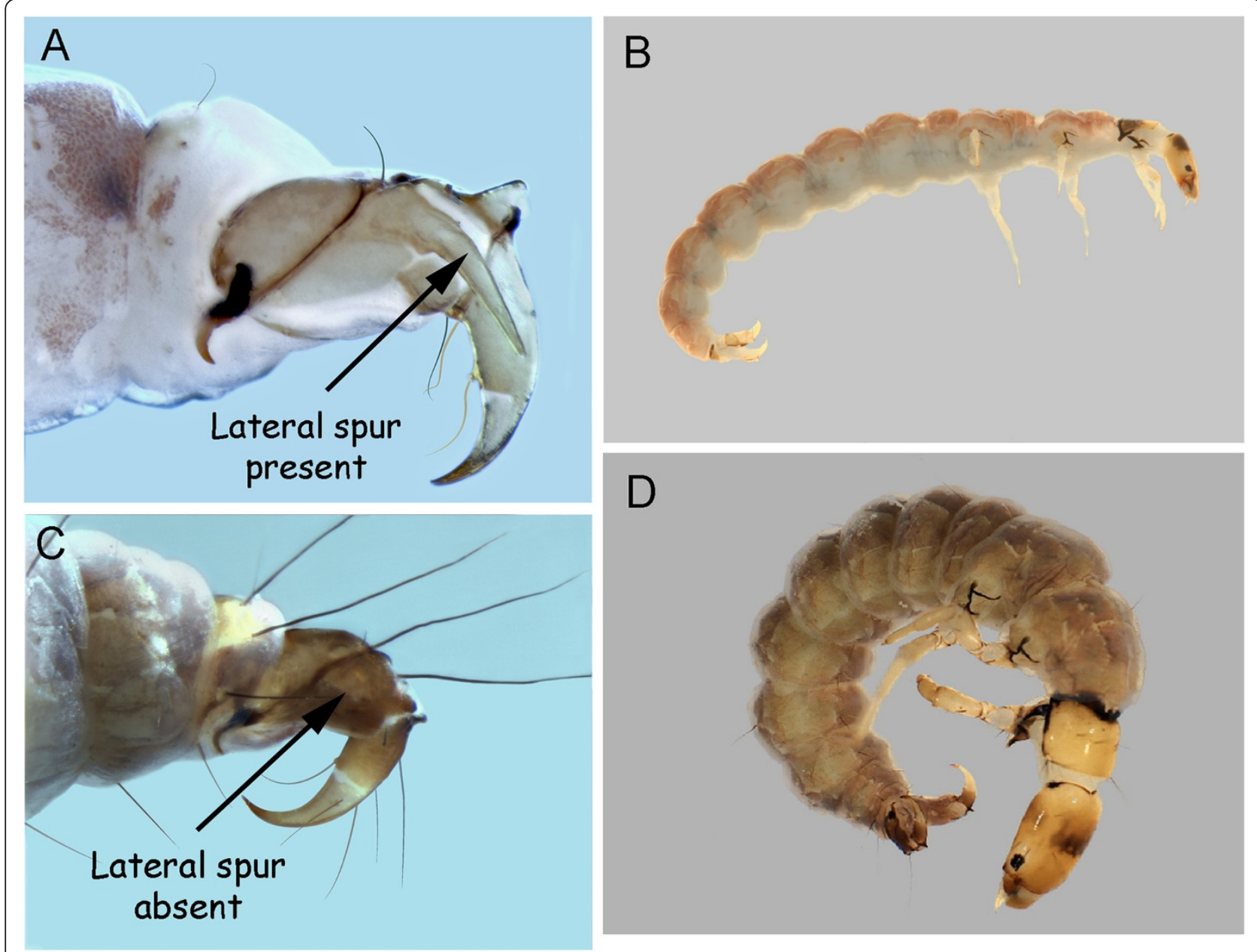

Figure 14 Rhyacophila angelita A: anal proleg, lateral; B: habitus, lateral; Rhyacophila mongolica C: anal proleg, lateral; D: habitus, lateral. 


\section{Table 2 Key for the Churchill, Manitoba, area Limnephilidae larvae}

1) all gill clusters with a single filament

9) basal trochantal segment with accessory setae (Figure $16 \mathrm{~A} \& \mathrm{~B}$ )

11) ventral apotome short, about half the length of ventral ecdysial suture (Figure 16C); metanotal sa1 and sa2 sclerites small or absent ventral apotome long, nearly reaching posterior margin (Figure 16D); metanotal sclerites large, obvious (Figure16E) 

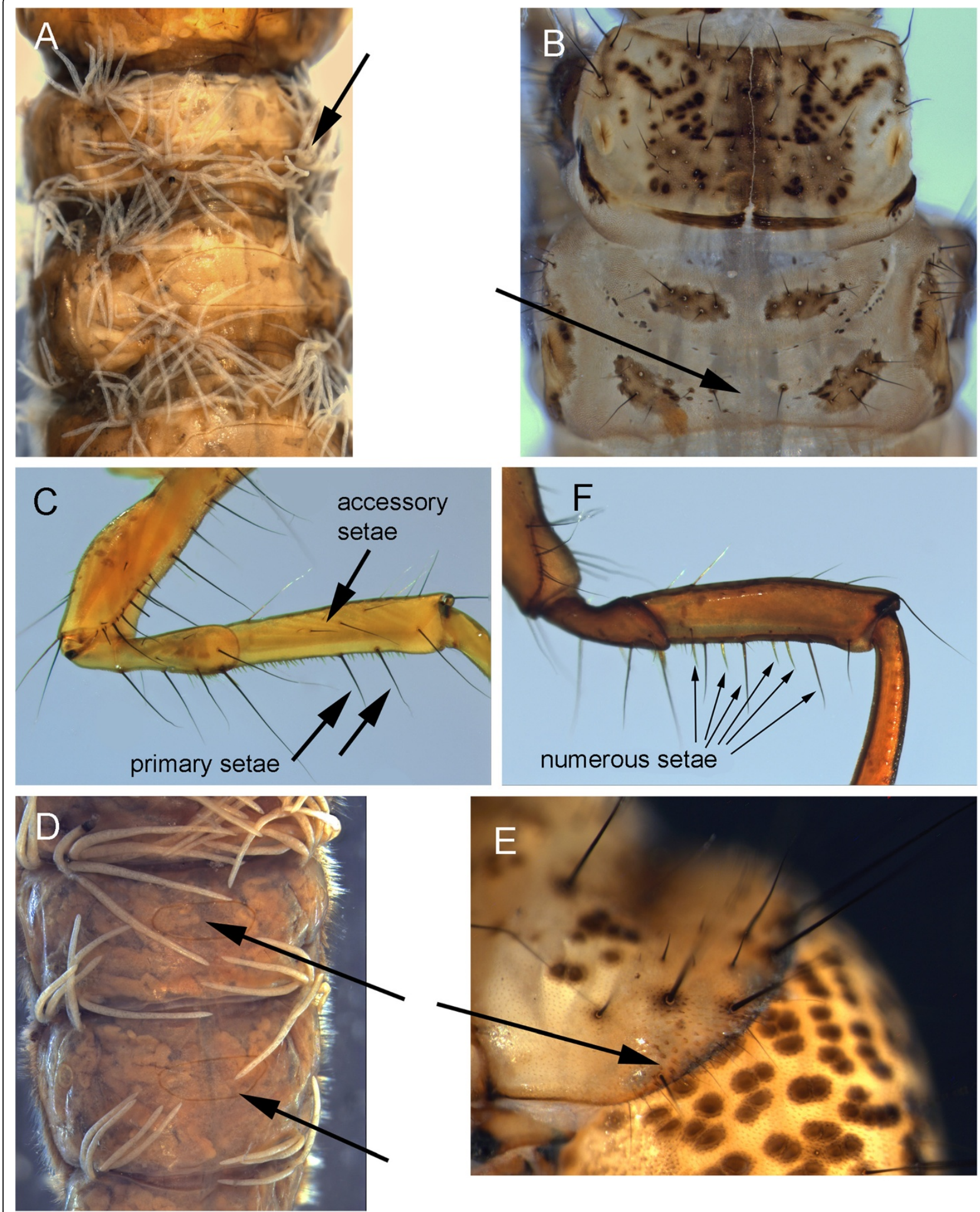

Figure 15 Lenarchus sp. A: abdomen, ventral; Asynarchus rossi; B: thorax, dorsal; Anabolia bimaculata C: 2nd leg, posterior view; D: abdomen, dorsal; E: prothorax, lateral; Onocosmoecus unicolor, F: 2nd leg, posterior. 
14) dorsum of head base color pale with a distinct U-shaped dark band (Figure 10C) base color of head dark (Figure 9l)

15) anterior of pronotum with transverse, wide dark band (Figure 16E) anterior of pronotom without wide, transverse dark band

16) head with three distinct dark bands dorsally against pale background (Figure 9G) head with dark areas and scattered darker muscle scars, without pale background laterally (Figure 9l)

17) pale blotches of frontoclypeal area all located within frontoclypeal sutures (Figure 8K) at least parts of frontoclypeal pale areas located laterad of frontoclypeal sutures (Figure 8J)

18) the two anterior frontoclypeal pale areas are round (Figure 8J) the two anterior frontoclypeal pale areas are linear and extend further forward along frontoclypeal suture (Figure 9H)

19) head with dark background color with darker muscle scars. Any pale areas are small and limited to the frontoclypeal area (Figure 9L) head with large pale areas not limited to frontoclypeal area (Figure 9A)

20) head monochromatic brown with little evidence of pale areas in frontoclypeal area (Figure 8L) head with pale areas in frontoclypeal area (Figure 10B)

21) anterior ventral apotome about half the length of the ecdysial suture (Figure 16C) anterior ventral apotome nearly as long as the ecdysial suture (Figure 16D)

22) frontoclypeal pale blotches extend anteriorly beyond eye (Figure 9K) frontoclypeal pale blotches do not extend anteriorly beyond eye (Figure 10B)

23) frontoclypeus without distinct linear dark stripe (Figure 9A) frontoclypeal stripe distinct (Figure 9D)

24) medial frontoclypeal band expanded anteriorly with dark coloration reaching anterior frontoclypeal corners (Figure 9C) medial frontoclypeal band not strongly expanded and without distinct dark coloration in anterior frontoclypeal corners (Figure 9F)

25) lateral dark bands of head reach posterior margin of head (Figure 9D) lateral dark bands curved mesad and not reaching posterior margin of head (Figure 9B)

26) mesonotal sa1 with numerous setae mesonotal sa1 with only a single seta (Figure 16F)
Nemotaulius hostilus

Limnephilus infernalis

Limnephilus nigriceps

Limnephilus alaicus

Limnephilus ademus

Limnephilus major

Limnephilus argenteus

Limnephilus picturatus

Limnephilus perpusillus

Limnephilus sericeus

Limnephilus canadensis

Limnephilus femoralis

Limnephilus externus Limnephilus extractus 

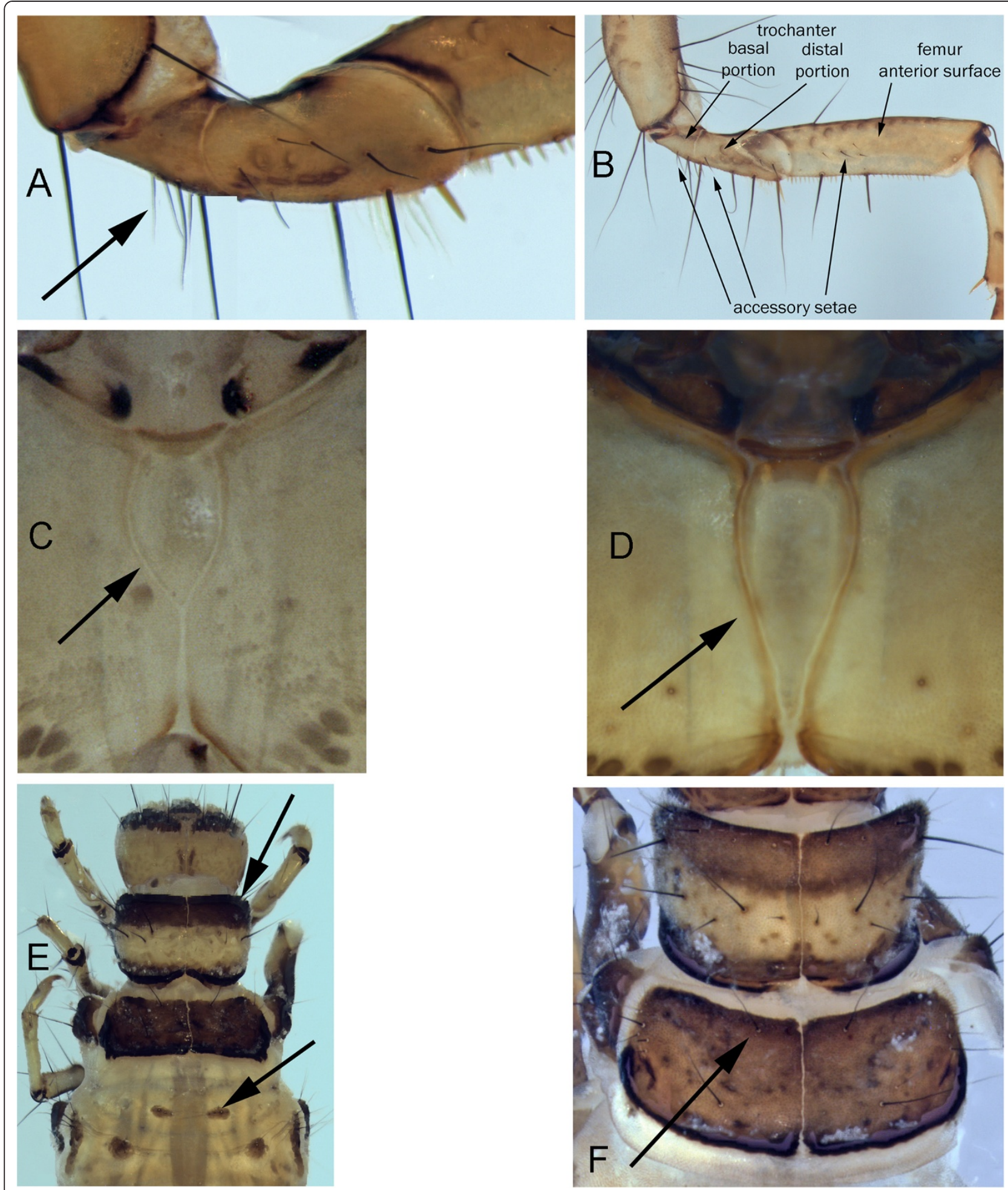

Figure 16 Asynarchus lapponicus A: mesotrochanter, posterior view; Philarctus bergrothi B: 2nd leg, anterior view; Arctopora pulchella C: ventral apotome; Grammotaulius interrogationis D: ventral apotome; Limnephilus infernalis E: thorax, dorsal; Limnephilus extractus F: thorax, dorsal. 


\section{Discussion}

Through the use of DNA barcoding, this study was able to associate larvae and adults for more than $2 / 3$ of the caddisfly fauna of the Churchill area. An additional 23 species were recorded for the Churchill region since previous reports, increasing the total species count to 91 for the area. Habitus pictures of the collected larvae and cases are contained in Figures 18, 19, 20, 21, 22, 23 and 24. These pictures should not be used for determining genus or species as cases are often not distinct within a species, and in some genera, highly variable. With molecularly identified larvae, unique morphological characters could be quickly distinguished for most larval species, and a taxonomic key for the Limnephilidae was built for the area. Thus, the integration of both DNA barcoding and larval taxonomy has allowed for the rapid identification and description of the Churchill Trichoptera fauna.

Obvious discrepancies in occurrence and abundance between adult or larval stages of many Churchill caddisflies have been observed. For instance, a total of 29 species were only represented by adults, while 11 species only by larvae (Table 1). At least for some species, e.g., Cheumatopsyche campyla complex, the collecting of larvae has been mainly limited by our sampling technology (dip net and hand picking) that is not suitable for large and deep river habitats. The failure in collecting either life stages for some species might be also due to their rarity and perhaps also the multi-year life cycle characters. Furthermore, a number of "rare" species defined by availability of adult numbers, have proved to be locally abundant after their larvae were collected, e.g., Brachycentrus americanus, Anabolia bimaculata, Limnephilus canadensis, L. nigriceps, Philarctus bergrothi. Thus, the sampling of multiple life-stages proved important for conducting comprehensive biodiversity surveys. Of course, the capability of identifying caddisfly larvae from the Churchill area also improves our understanding of the life history and biodiversity distribution (across microhabitats) of these important freshwater macroinvertebrates.

The successful association of a significant portion of Churchill's caddisfly larvae is also contributing to studies in larval systematics and phylogenetics of several key trichopteran lineages, e.g., Limnephilidae. In Brachycentridae, adults of Brachycentrus fuliginosus were collected. This is the only recent record for this rare taxon that we are aware of. Once the larvae are found and associated via DNA, the description of the larvae will complete the larval descriptions for all North American Brachycentrus. Another group where the systematics and phylogeny are rapidly changing is Limnephilidae [44]. The many Churchill Limnephilus larvae associations will greatly improve our ability to understand the systematics of this group.

While this study demonstrated the successful application of DNA barcoding for linking life stages in Trichoptera, this approach can be applied to other taxonomic groups. Many taxonomic groups also suffer from the same limitations as in Trichoptera, where the taxonomic literature is written for adults and immature rearing is a difficult endeavor. This limitation has been recognized by a number of researchers, who have successfully employed DNA barcoding to associate different life stages of beetles [50], midges [51], earthworms [52], marine planktonic larvae [53], and shrimp [54]. There are also practical applications of this approach, such as the detection of invasive marine diapausing eggs in ship ballast water [55]. Of course, authors have noted $[51,56]$ that the utility of this approach is dependent on a comprehensive reference library of identified adults with COI sequences. However, this issue is less problematic if identifiable adults are simultaneously collected and sequenced in the same local area. In addition, as 


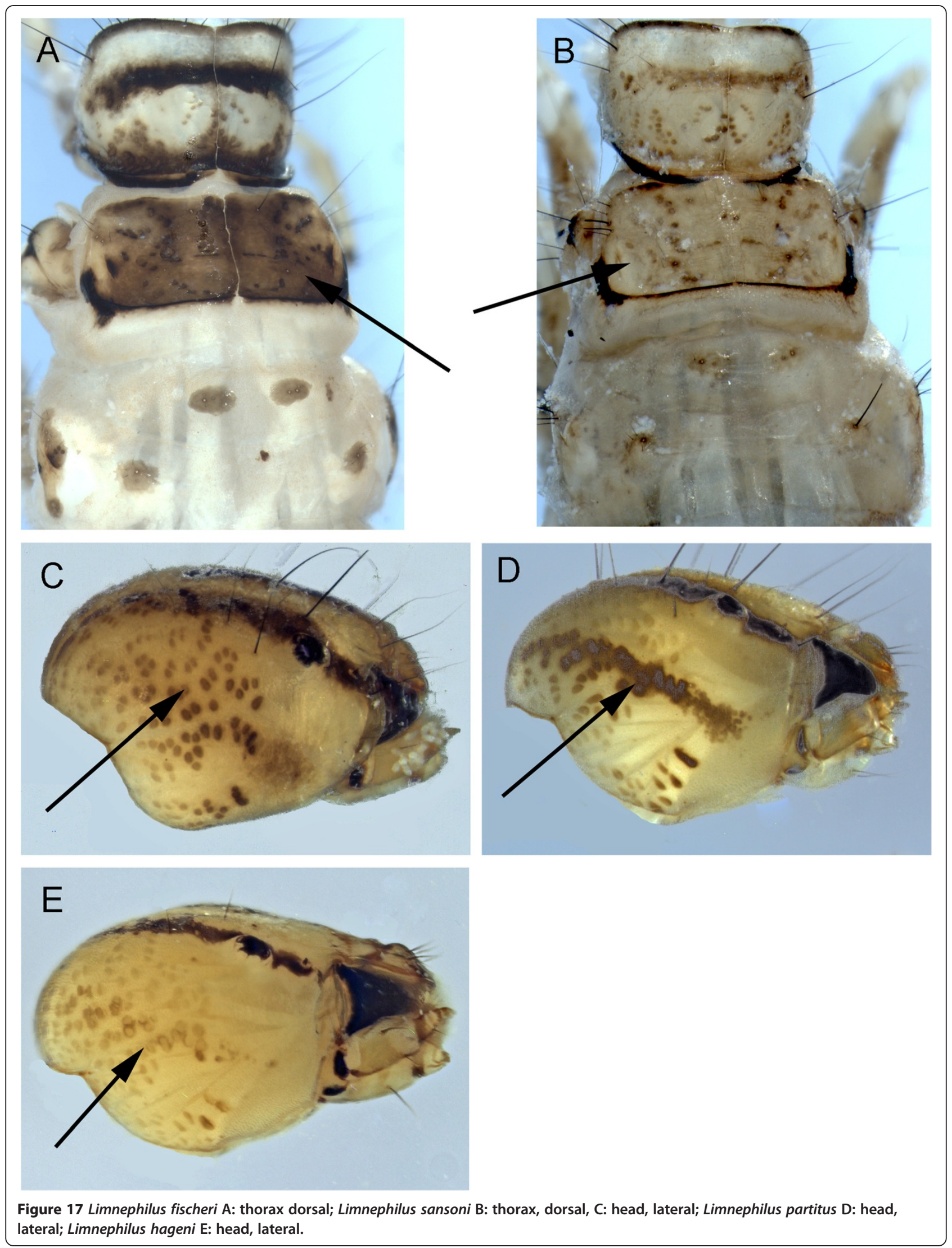




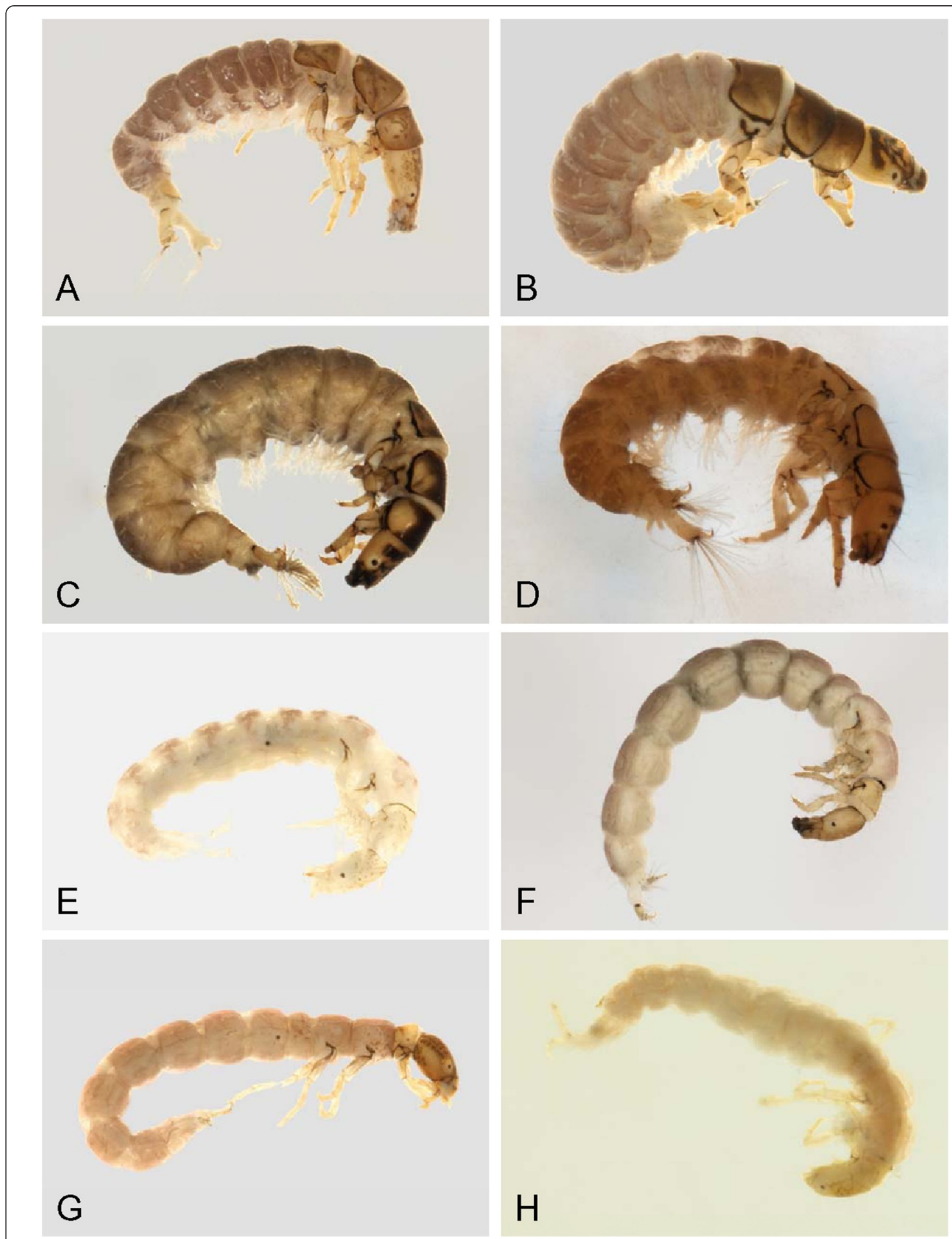

Figure 18 Hydropsychidae, lateral view A: Arctopsyche ladogensis, B: Hydropsyche alternans, C: Hydropsyche bronta, D: Hydropsyche vexa; Polycentropodidae, lateral view E: Neureclipsis crepuscularis, F: Neureclipsis valida, G: Polycentropus aureoles, H: Polycentropus smithae. 

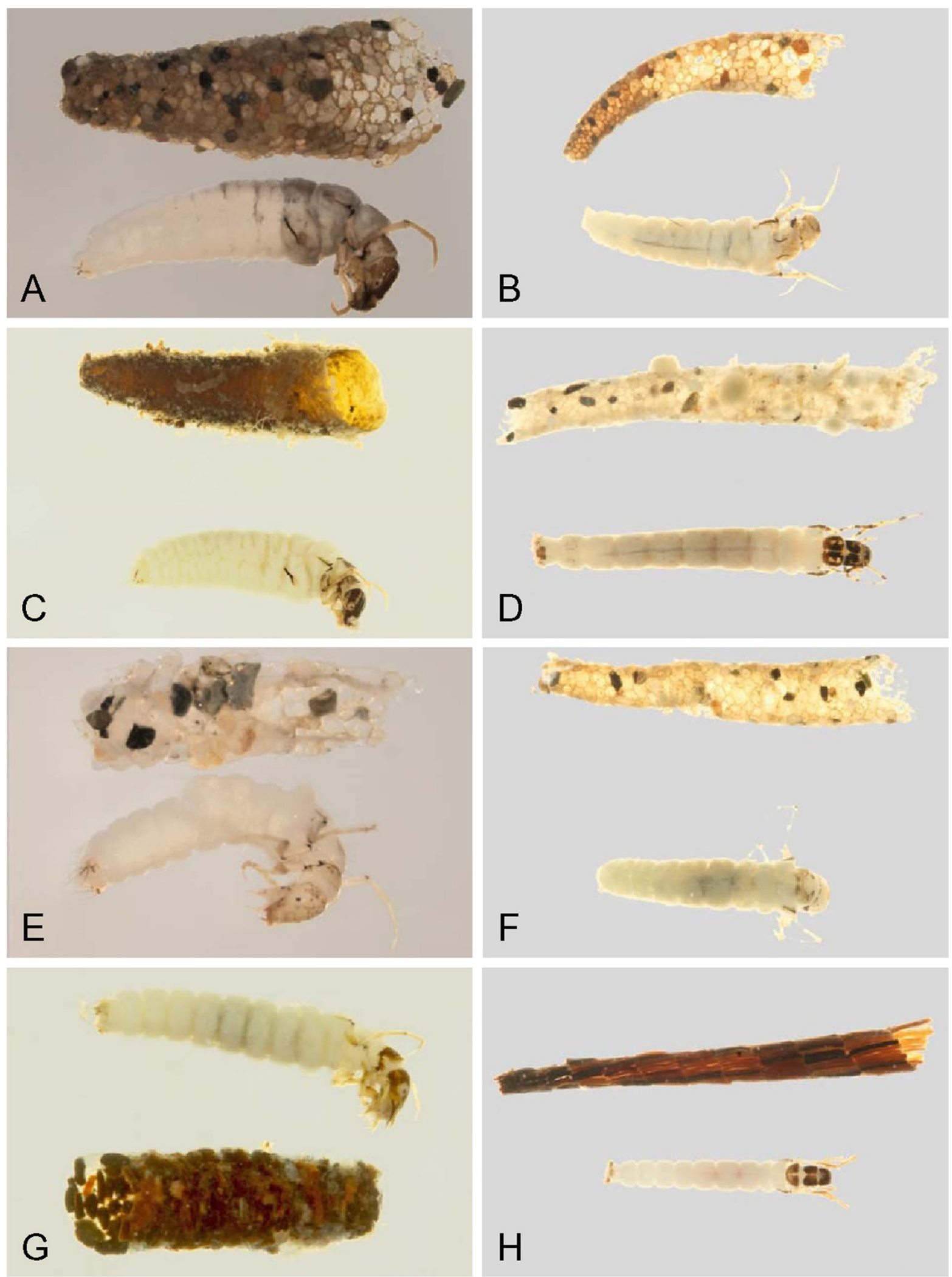

Figure 19 Leptoceridae A: Ceraclea annulicornis, lateral; B: Ceraclea excisa, dorsal; C: Ceraclea nigronervosa, lateral; D: Mystacides interjecta, dorsal; E: Oecetis cf. ochracea CHU1, lateral; F: Oecetis immobilis, dorsal; G: Oecetis ochracea, lateral; H: Triaenodes frontalis, dorsal. 


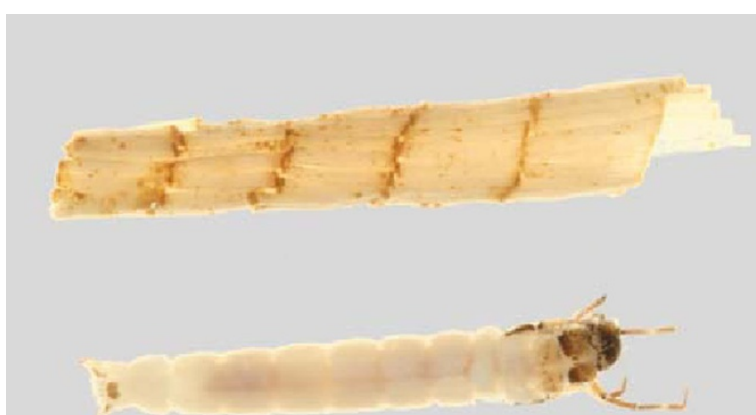

A
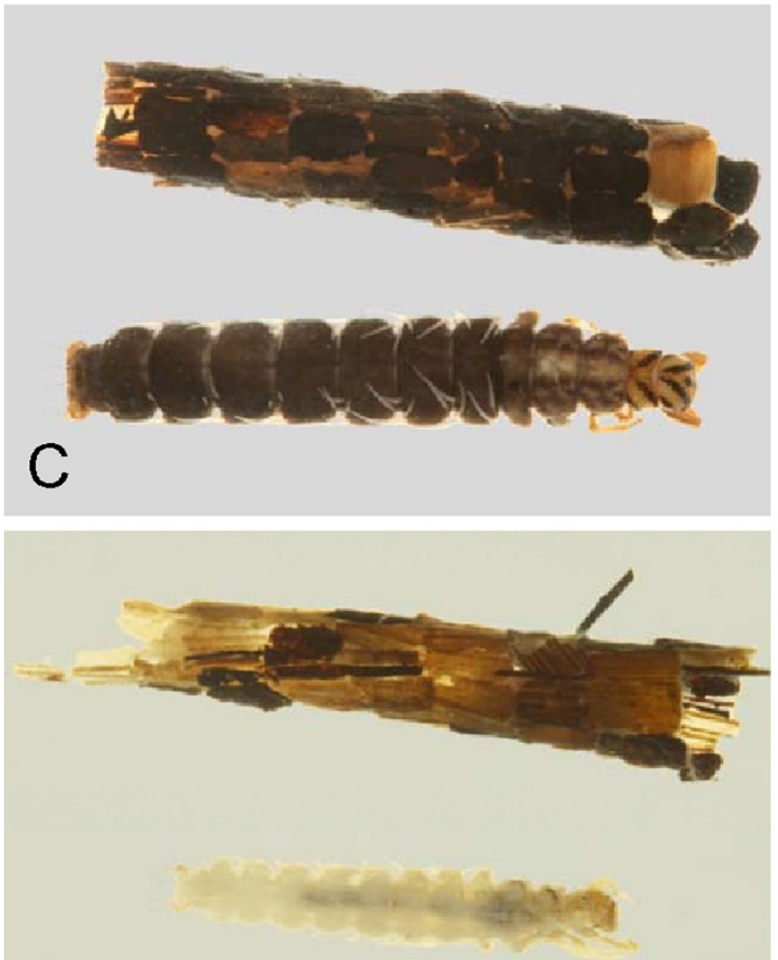

$E$

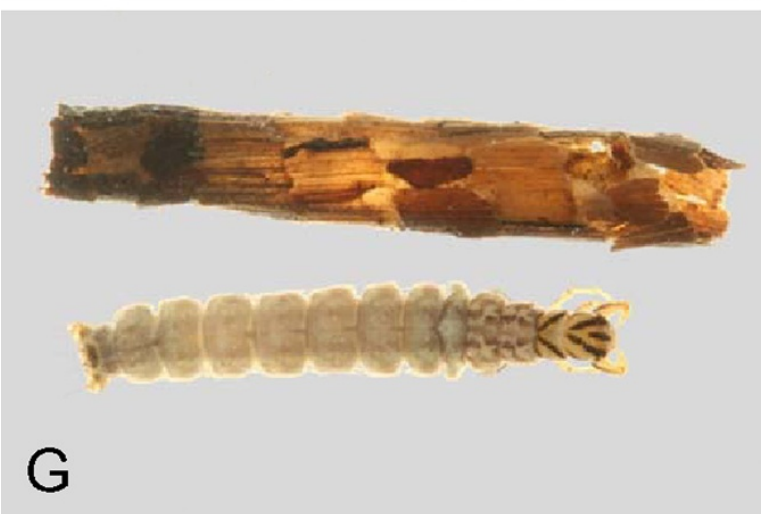

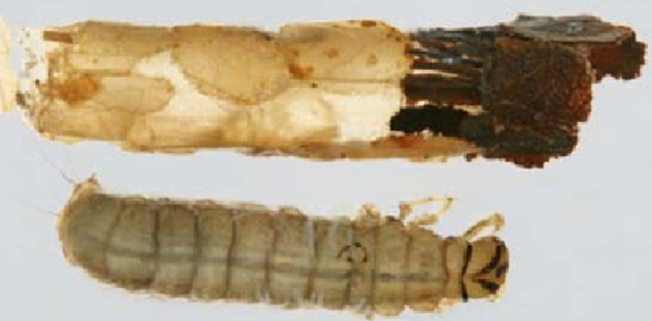

B
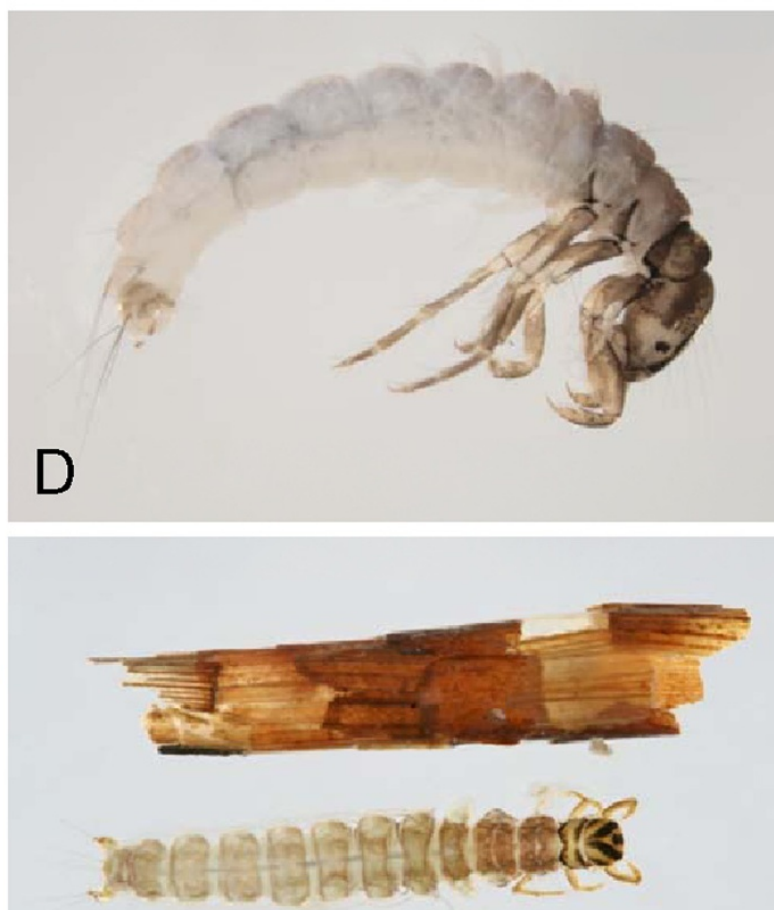

$\mathrm{F}$

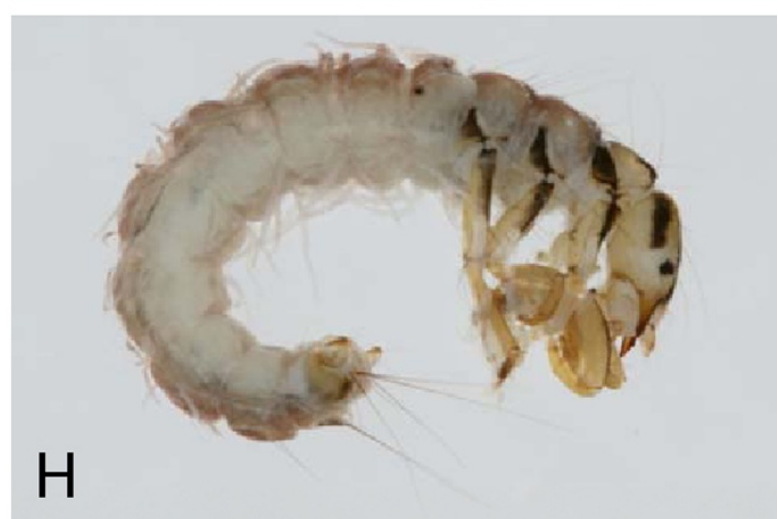

Figure 20 Leptoceridae A: Triaenodes reuteri, lateral; Phryganeidae B: Agrypnia colorata, dorsal; C: Agrypnia deflata, dorsal; D: Agrypnia glacialis, lateral; E: Agrypnia improba, ventral; F: Agrypnia pagetana, dorsal; G: Agrypnia straminea, dorsal; H: Banksiola crotchi, lateral. 

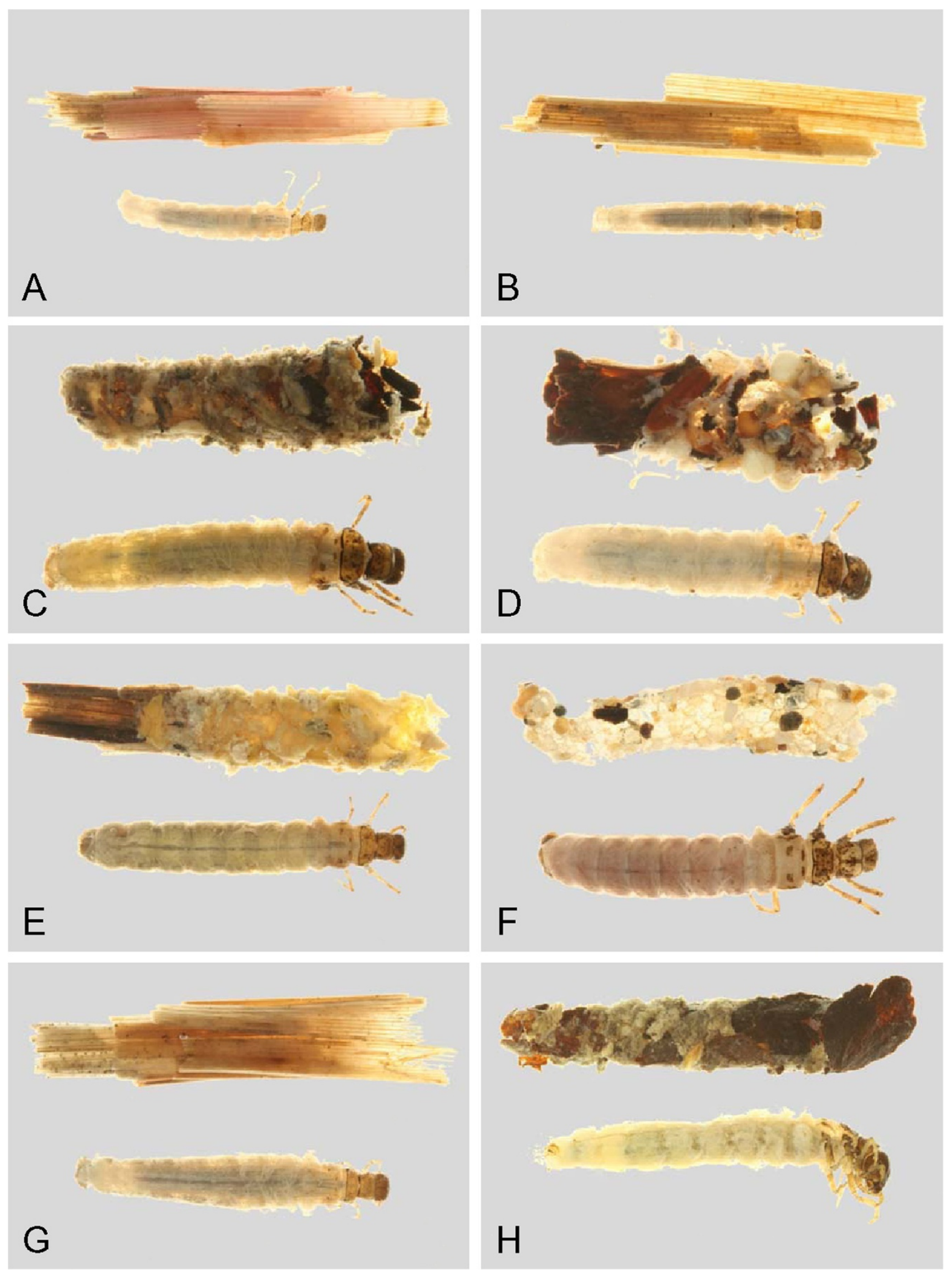

Figure 21 Limnephilidae A: Anabolia bimaculata, dorsal; B: Arctopora pulchella, dorsal; C: Asynarchus lapponicus, dorsal; D: Asynarchus montanus, dorsal; E: Asynarchus mutatus, dorsal; F: Asynarchus rossi, dorsal; G: Grammotaulius interrogationis, dorsal; H: Lenarchus fautini, lateral. 

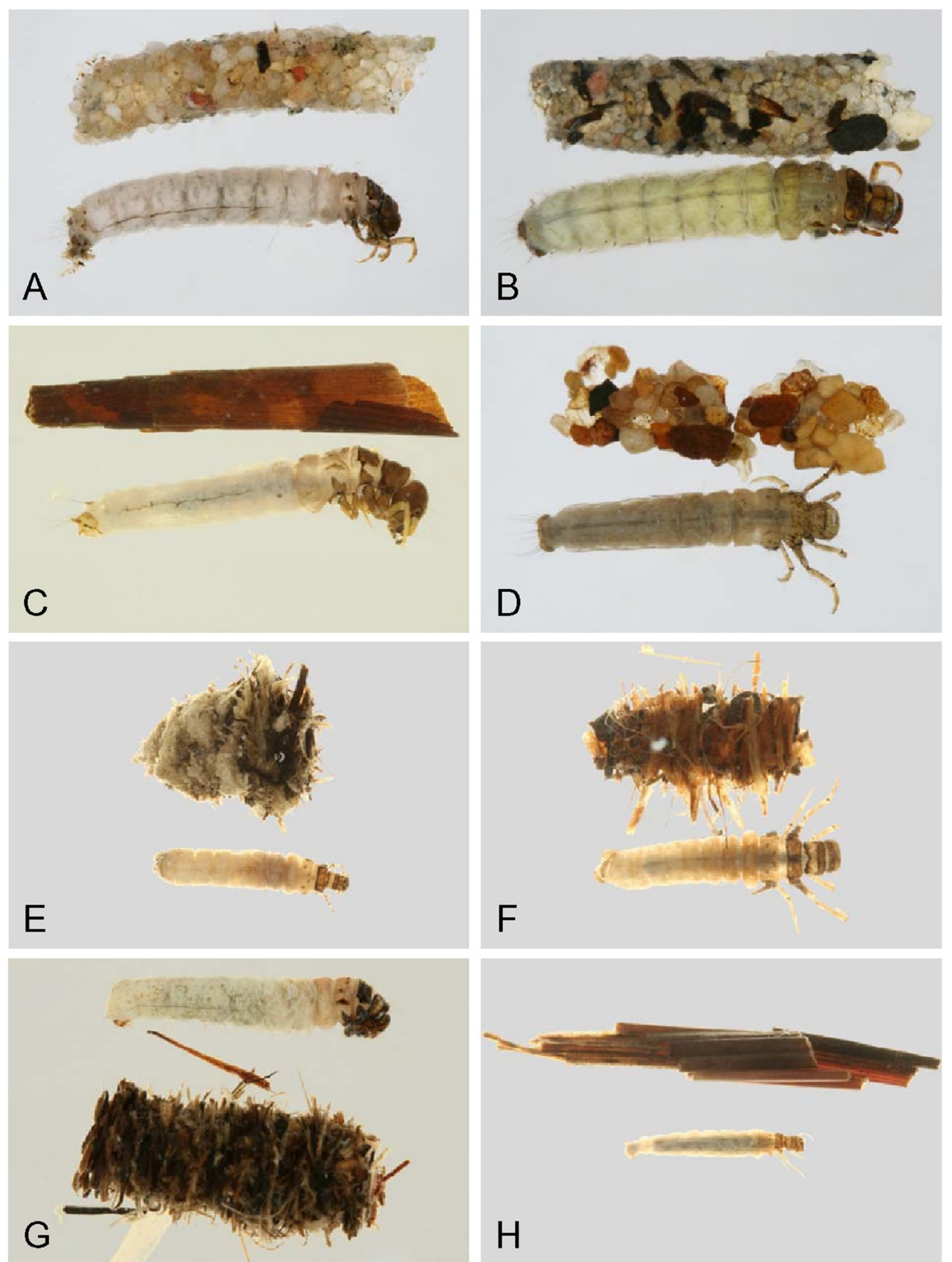

Figure 22 Limnephilidae A: Limnephilus ademus, lateral; B: Limnephilus alaicus, dorsal; C: Limnephilus argenteus, lateral; D: Limnephilus canadensis, dorsal; E: Limnephilus externus, dorsal; F: Limnephilus extractus, dorsal; G: Limnephilus femoralis, lateral; H: Limnephilus fischeri, dorsal. 

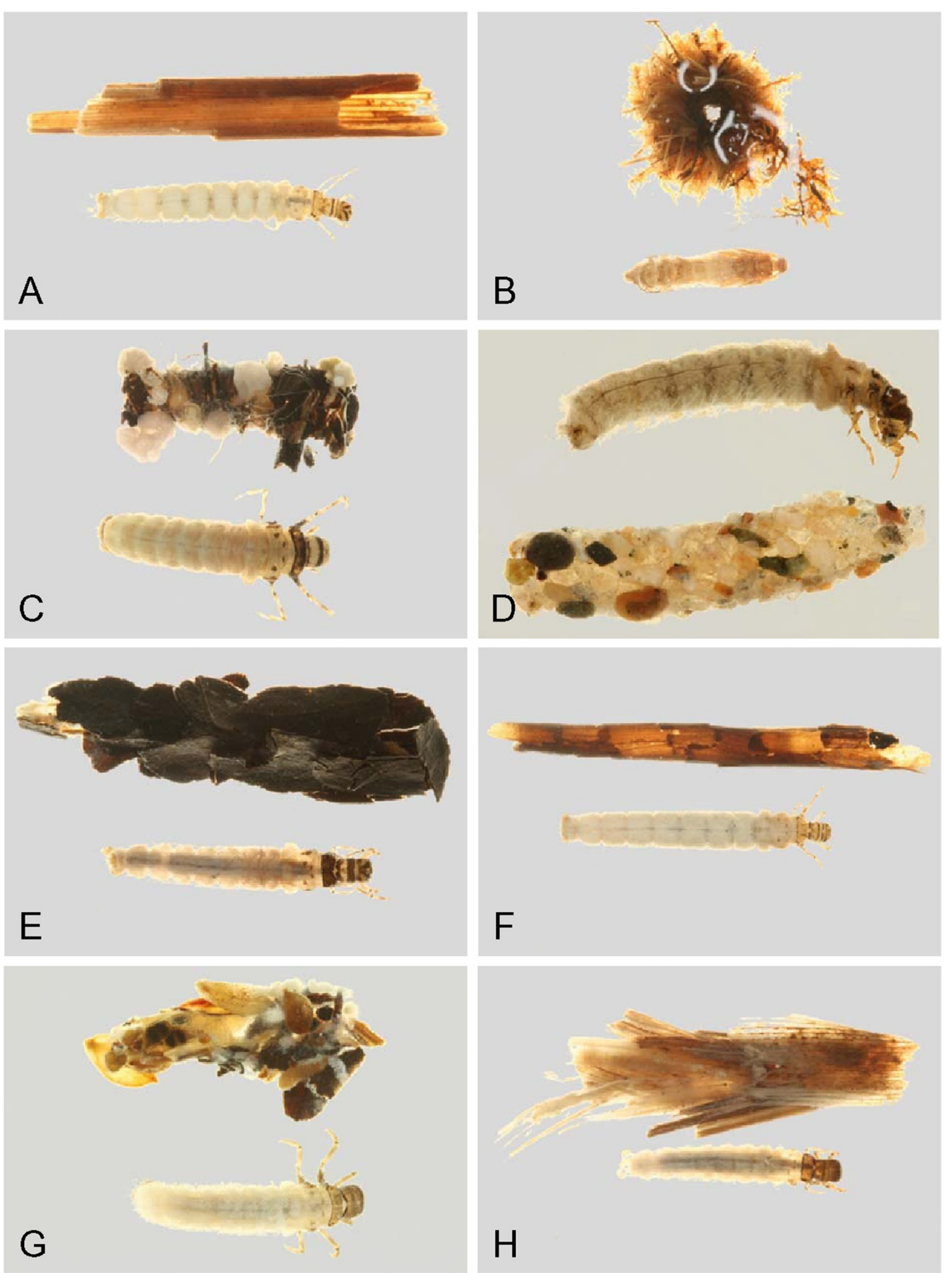

Figure 23 Limnephilidae A: Limnephilus hageni, dorsal; B: Limnephilus indivisus, dorsal; C: Limnephilus infernalis, dorsal; D: Limnephilus major, lateral; E: Limnephilus nigriceps, dorsal; F: Limnephilus partitus, dorsal; G: Limnephilus perpusillus, dorsal; H: Limnephilus picturatus, dorsal. 


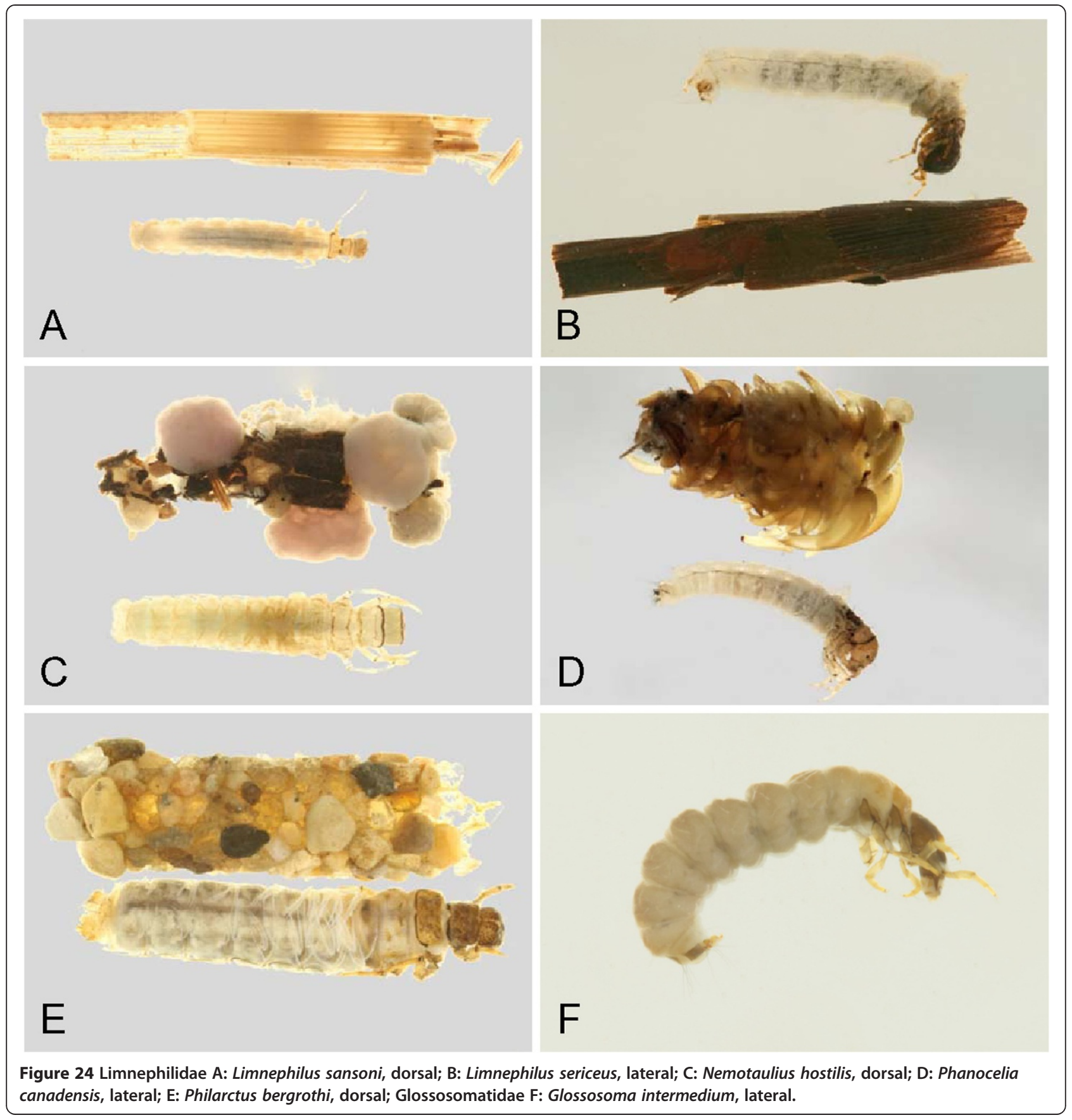

more COI sequences are generated from identified adults, this issue will become less of an impediment.

While this study has demonstrated the effectiveness of DNA barcoding approaches to understanding biodiversity at a local level and associating different life stages, much more work is required to catalog the North American Trichoptera diversity. It is hoped more taxonomists and field biologists submit material for DNA association with the goal of rapidly improving our ability in North America to determine all life stages to the species level. Funding agencies also need to recognize the value of such analyses and provide concurrent funding for field collection, DNA analysis, and comparative morphological evaluations. Ideally, funding would be provided to examine both adult and larval stages to build upon the current COI reference library, and to contribute a broader understanding of Trichoptera biodiversity and ecology.

The DNA barcode reference library, taxonomic descriptions, and keys generated in this study will be 
a valuable aid for future studies on Trichoptera larvae in the Churchill region. This work provides researchers the tools to take either a molecular or morphological approach to species-level identification. It is expected that these resources will be of use to future ecological and biodiversity studies in the area.

\section{Conclusions}

Associating different life stages of Trichoptera in the Churchill, MB area by applying both morphology and DNA barcoding proved highly successful. This study has provided researchers with diagnostics for nearly all caddisfly larvae available from the Churchill region to date and a taxonomic key for the limnephilid larvae to utilize in future biodiversity and ecological research in the area.

\section{Methods}

\section{Specimen collection and sorting}

Specimens were collected from the sub-arctic location of Churchill, MB, Canada during July 17 - August 2, 2009, and over a 12-week period from June 5 - August 25, 2010, in addition to prior collecting effort since 2002 $[7,8]$. Sampling included a variety of freshwater locations including coastal saline and freshwater rock pools, tundra ponds, lakes, creeks, and along the Churchill River. In total, 75 sites were visited once a month for three months in 2010, and these included the sites from which collections were made in 2009.

Trichoptera larvae were collected using a dip net as well as hand collections involving investigating under rocks and debris. Collected specimens were preserved in 95\% ethanol and photographed with their case using a Cannon EOS 30D and an EOS 50D. Specimens were identified to family based on Wiggins [37] and further sorted into morphospecies based on variation in head and thoracic markings, case type, habitat sampled, and time collected. For each hypothesized morphospecies, 10 specimens were selected for DNA sequencing except for a few species showing adaptation to a broad range of salinity, where more individuals were analyzed in 2009. If a hypothesized morphospecies contained several lineages based on the COI clustering and barcode identification, further specimens were sampled. All samples are stored at the Biodiversity Institute of Ontario at the University of Guelph, Guelph, ON, Canada.

\section{Molecular analysis}

Specimens had one leg sub-sampled, and molecular methods followed standard manual DNA barcoding protocols [57]. DNA was extracted using an AcroPrep 96 well $3.0 \mu \mathrm{m}$ glass fibre plate and was eluted with $50 \mu \mathrm{l}$ of water. Extracted DNA was then amplified for the 658 bp COI region using polymerase chain reaction
(PCR) using a $12.5 \mu \mathrm{l}$ reaction volume. This reaction was comprised of $6.25 \mu \mathrm{l} 10 \%$ trehalose (D-(+)-Trehalose

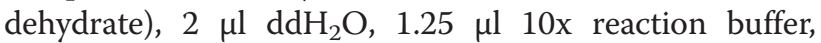
$0.625 \mu \mathrm{l} 50 \mathrm{mM} \mathrm{MgCl} 2,0.0625 \mu \mathrm{l} 10 \mathrm{mM}$ dNTP, $0.06 \mu \mathrm{l}$ $5 \mathrm{U} / \mu \mathrm{l}$ Taq DNA polymerase (Invitrogen), $0.125 \mu \mathrm{l}$ of $10 \mu \mathrm{M}$ of both forward and reverse primer, and $2 \mu \mathrm{l}$ of DNA. The primers used in this study to amplify COI included a primer cocktail of two forward primers: LepF1 ATTCAACCAATCATAAAGATATTGG, LCO1490 - GG TCAACAAATCATAAAGATATTGG; and two reverse primers: LepR1 - TAAACTTCTGGATGTCCAAAAAAT CA, and HCO2198 - TAAACTTCAGGGTGACCAAAAA ATCA [58,59], for full-length barcodes. Additionally, two sets of primers (MEPTR1-t1 and MLepR1) paired with routine reverse and forward primers, respectively, targeting the first and second halves of the full-length barcode regions were employed following Zhou et al. [7]. The PCR reaction was thermocycled for $94^{\circ} \mathrm{C}$ 1 min; 5 cycles of $94^{\circ} \mathrm{C} 40 \mathrm{~s}, 45^{\circ} \mathrm{C} 40 \mathrm{~s}, 72^{\circ} \mathrm{C} 1 \mathrm{~min} ; 35$ cycles of $94^{\circ} \mathrm{C} 40 \mathrm{~s}, 51^{\circ} \mathrm{C} 40 \mathrm{~s}, 72^{\circ} \mathrm{C} 1 \mathrm{~min}$; held at $72^{\circ} \mathrm{C}$ for $5 \mathrm{~min}$, and stored at $4^{\circ} \mathrm{C}$. Successful PCR reactions were checked using an Invitrogen $2 \%$ agarose E-gel ${ }^{\circledR}$ with an ethidium bromide stain and developed with UV and if successful, were subsequently bi-directionally sequenced using BigDye ${ }^{\circledR}$ and a Applied Biosystems 3730XL DNA analyzer [60]. All information associated with each specimen, including collection information, taxonomy, photograph, and the COI sequence, were uploaded to BOLD.

\section{Tree Construction}

COI sequences were downloaded from BOLD and combined into unique haplotypes using a script written in Python. All unique COI haplotypes were used to construct a NJ tree using MEGA v5.0 [61], using a Neighbor-Joining method [62] with pairwise deletion of missing sites and Kimura-2-Parameter (K2P) distances [63]. Terminal nodes were collapsed into triangles, where the height represented the number of unique haplotypes and the length represented intraspecific divergence. Species represented by both adult and larval specimens were marked in purple color; those represented only by adults were marked in blue; and those by only larvae were marked by green (Figure 1). Numbers in brackets after each species name represent the number of unique COI haplotypes and the number of individuals sequenced, respectively.

\section{Larval-Adult Association}

This work has used COI to verify larval associations, a process which can greatly reduce the time and effort necessary to associate larvae with the corresponding adult, especially when metamorphotypes [64] cannot be located at the time of collection. The molecular identification of larval specimens followed criteria proposed by Zhou et al. 
[5]. Briefly, a species was assigned to a larval specimen when its DNA barcode shared identical sequence with a barcode reference obtained from an identifiable adult specimen (typically a male specimen), or alternatively, if the larval sequence fell in a species boundary defined by adult sequences on a phylogenetic tree.

\section{Morphology}

Morphological comparisons were made for all DNA determined larval taxa. At least two specimens of each taxon were compared for variability whenever possible. When only limited/immature specimens were available for morphological and DNA character analysis, it is noted in the text. Illustrations were prepared and processed for characteristic structures with the use of compound and stereo microscopes, Xnview $\odot$, Automontage $\odot$, Zerene Stacker@, and Photoshop@ $\odot$. Material extraneous to the character in question was often removed electronically and other characters such as a characteristic seta were occasionally added when the original structure was broken. Terminology follows that of Wiggins [21].

The larval keys presume the readers have suitable publications for determining specimens to genus $[21,64]$. Habitus pictures of the available larvae and cases are contained in Figures 18, 19, 20, 21, 22, 23 and 24. These pictures should not be used for determining genus or species as cases are often not distinct within a species, and in some genera, highly variable. We have selected habitus pictures based on their availability and clarity.

\section{Competing interests}

The authors declare that they have no competing interests.

\section{Authors' contributions}

All authors were involved in the conceptual design. EEB and XZ carried out the collection and sorting of specimens. DER and XZ performed the morphological identifications. DER wrote the species diagnoses, taxonomic description, and key. DER, EEB, and the Imaging Department at the Biodiversity Institute of Ontario took the photographs. EEB and XZ performed the DNA sequencing, editing, and alignment. XZ performed the molecular analysis. All authors helped draft the text and approved the final manuscript.

\section{Acknowledgements}

DER would like to acknowledge Joe Giersch for exceptional assistance with photographic techniques used in the various morphological larval photos. Funding for this project was provided by the Natural Sciences and Engineering Research Council of Canada (NSERC) through a Northern Research Internship to EEB and Discovery Grant to Sarah Adamowicz (University of Guelph), the Government of Canada through Genome Canada and the Ontario Genomics Institute (OGI) to the International Barcode of Life (iBOL) Project, led by Paul Hebert (University of Guelph), Canadian Foundation for Innovation (CFI), Ontario Ministry of Research and Innovation, Churchill Northern Studies Centre (CNSC) through Northern Research Fund awards to EEB and XZ, and the Department of Aboriginal Affairs and Northern Development Canada through a Northern Scientific Training Program award to EEB. We also thank the Ontario Ministry of Economic Development and Innovation for funding the ongoing development of BOLD, which was essential for data management and analysis for this project. We are grateful to the staff of the Canadian Centre for DNA Barcoding (CCDB) at the University of Guelph for the molecular analysis of specimens.

\section{Author details}

'235 SW Central Avenue, Grants Pass, OR 97526, USA. ²Department of Integrative Biology, University of Guelph, 50 Stone Rd. E, Guelph, ON N1G 2 W1, Canada. ${ }^{3}$ BGI-Shenzhen, Beishan Rd., Yantian District, Shenzhen, Guangdong Province 518083, China.

Received: 27 June 2012 Accepted: 24 September 2012 Published: 20 February 2013

\section{References}

1. Holzenthal RW, Blahnik RJ, Prather AL, Kjer KM: Order Trichoptera Kirby, 1813 (Insecta), Caddisflies. Zootaxa 2007, 1668:639-698.

2. Mackay RJ, Wiggins GB: Ecological diversity in Trichoptera. Annu Rev Entomol 1979, 24:185-208.

3. Wiederholm T: Responses of aquatic insects to environmental pollution. In The Ecology of Aquatic Insects. Edited by Resh VH, Rosenberg DM. New York, NY: Praeger Publishers; 1984:508-557.

4. Wallace JB, Grubaugh JW, Whiles MR: Biotic indices and stream ecosystem processes: results from an experimental study. Ecol Appl 1996, 6:140-151.

5. Zhou X, Kjer KM, Morse JC: Associating larvae and adults of Chinese Hydropsychidae caddisflies (Insecta:Trichoptera) using DNA sequences. Journal of the North American Benthological Society 2007, 26:719-742.

6. Hogg ID, Smith BJ, Banks JC, DeWaard JR, Hebert PDN: Testing use of mitochondrial $\mathrm{CO}$ sequences for the identification and phylogenetic analysis of New Zealand caddisflies (Trichoptera). N Z J Mar Freshw Res 2010, 43:1137-1146.

7. Zhou X, Adamowicz SJ, Jacobus LM, Dewalt RE, Hebert PDN: Towards a comprehensive barcode library for arctic life - Ephemeroptera, Plecoptera, and Trichoptera of Churchill, Manitoba, Canada. Frontiers in Zoology 2009, 6:30,

8. Zhou X, Jacobus LM, DeWalt RE, Adamowicz SJ, Hebert PDN: Ephemeroptera, Plecoptera, and Trichoptera fauna of Churchill (Manitoba, Canada): insights into biodiversity patterns from DNA barcoding. Journal of the North American Benthological Society 2010, 29:814-837.

9. Zhou X, Robinson JL, Geraci CJ, Parker CR, Flint OS, Etnier DA, Ruiter D, DeWalt RE, Jacobus LM, Hebert PDN: Accelerated construction of a regional DNA-barcode reference library: caddisflies (Trichoptera) in the Great Smoky Mountains National Park. Journal of the North American Benthological Society 2011, 30:131-162.

10. Graf W, Lubini V, Pauls S: Larval description of Drusus muelleri McLachlan, 1868 (Trichoptera: Limnephilidae) with some notes on its ecology and systematic position within the genus Drusus. Annales de Limnologie International Journal of Limnology 2005, 41:93-98.

11. Graf W, Pauls SU, Waringer J: The larva of Rhyacophila ferox Graf, 2006 (Trichoptera: Rhyacophilidae) from the Eastern Alps (Carinthia, Austria). Aquatic Insects 2009, 31:111-117.

12. Graf W, Waringer J, Pauls SU: A new feeding group within larval Drusinae (Trichoptera: Limnephilidae): the Drusus alpinus Group sensu Schmid, 1956, including larval descriptions of Drusus franzi Scmid, 1956, and Drusus alpinus (Meyer-Dür, 1875). Zootaxa 2009, 2031:53-62

13. Pauls SU, Theissinger K, Ujvarosi L, Balint M, Haase P: Patterns of population structure in two closely related, partially sympatric caddisflies in Eastern Europe: historic introgression, limited dispersal, and cryptic diversity. Journal of the North American Benthological Society 2009, 28:517-536.

14. Zhou X: The larvae of Chinese Hydropsychidae (Insecta: Trichoptera), Part I: Arctopsyche shimianensis, Parapsyche sp. A, and Diplectrona obscura. Zootaxa 2009, 2174:1-17.

15. Harvey LE, Geraci CJ, Robinson JL, Morse JC, Kjer KM, Zhou X: Diversity of mitochondrial and larval morphology characters in the genus Diplectrona (Trichoptera: Hydropsychidae) in the eastern United States. Terrestrial Arthropod Reviews 2012, 5:1-12.

16. Ratnasingham S, Hebert PDN: BOLD: the barcode of life data system. Molecular Ecology Notes 2007, 7:355-364. www.barcodinglife.org.

17. Lepneva SG: Fauna of the USSR, Trichoptera II(2). Larvae and pupae of the Integripalpia. Zoological Institute of the Academy of Science of the USSR New Series 1971, 95:1-700.

18. Solem JO: Larval and pupal descriptions of Asynarchus contumax McLachlan, 1880, and A. lapponicus Zetterstedt, 1840, with notes on bionomics in Centr. Norway (Trichoptera: Limnephilidae). Entomologica Scandinavica 1983, 14:439-451. 
19. Flint OS: The genus Brachycentrus in North America, with a proposed phylogeny of the genera of Brachycentridae (Trichoptera). Smithsonian Contributions to Zoology 1984, 398:1-58

20. Harrington RC, Morse JC: A new species of Brachycentrus Curtis (Trichoptera: Brachycentridae) from the southern Appalachian Mountains and variation in the caddisfly B. spinae Ross. Proc Entomol Soc Wash 2004, 106:453-459.

21. Wiggins GB: Larvae of the North American Caddisfly Genera (Trichoptera). 2nd edition. Toronto, ON: University of Toronto Press; 1996:pp457.

22. Schuster GA, Etnier DA: A manual for the identification of the larvae of the caddisfly genera Hydropsyche Pictet and Symphitopsyche Ulmer in eastern and central North America (Trichoptera: Hydropsychidae). Cincinnati, OH: 1978. Report Num. EPA-600/4-78-060.

23. Schefter PW, Wiggins GB: A systematic study of the Nearctic larvae of the Hydropsyche morosa Group (Trichoptera: Hydropsychidae). Toronto, ON: Life Sciences Miscellaneous Publications, Royal Ontario Museum; 1986.

24. Lepneva SG: Fauna of the USSR, Trichoptera II(1). Larvae and pupae of the Annulipalpia. Zoological Institute of the Academy of Science of the USSR, New Series 1970, 88:1-638.

25. Weaver JS: A synopsis of the North American Lepidostomatidae (Trichoptera). Contributions of the American Entomological Institute 1988, 24:1-141.

26. Resh $\mathrm{VH}$ : The biology and immature stages of the caddisfly genus Ceraclea in Eastern North America (Trichoptera: Leptoceridae). Ann Entomol Soc Am 1976, 69:1039-1061.

27. Yamamoto T, Wiggins GB: A comparative study of the North American species in the caddisfly genus Mystacides (Trichoptera: Leptoceridae). Can J Zool 1964, 42:1105-1126.

28. Floyd MA: Larvae of the caddisfly genus Oecetis (Trichoptera: Leptoceridae) in North America. Bulletin of the Ohio Biological Survey, New Series 1995, 10:1-85.

29. Glover JB: Larvae of the caddisfly genera Triaenodes and Ylodes (Trichoptera: Leptoceridae) in North America. Bulletin of the Ohio Biological Survey, New Series 1996, 11:1-89+vii.

30. Betten C: The caddisflies or Trichoptera of New York State. New York State Museum Bulletin 1934, 292:1-576.

31. Denning DG: The biology of some Minnesota Trichoptera. Transactions of the American Entomological Society 1937, 63:17-43.

32. Flint OS: Taxonomy and biology of Nearctic limnephilid larvae (Trichoptera), with special reference to species in eastern United States. Entomologica Americana 1960, :1-120.

33. Schmid F: Le genre Asynarchus McL. (Trichopt., Limnoph.). Mitteilungen der Schweizerischen Entomologischen Gesellschaft 1954, 27:57-96.

34. Ruiter D: Initial list of Trichoptera collected in the USA by 1995 Symposium participants. Braueria 1996, 23:10-12.

35. Lloyd JT: The biology of North American caddis fly larvae. Bulletin of the LLoyd Library of Botany, Pharmacy and Materia Medica, Entomological Series 1921, 1:1-124.

36. Hoopes RL: Taxonomy and biology of Anabolia and Limnephilus (Trichoptera: Lirnnephilidae) in Pennsylvania, with an annotated list of the Trichoptera of Pennsylvania. Pensylvannia State University, MSC thesis 1976, 1-131.

37. Wiggins GB: Larvae of the North American caddisfly genera (Trichoptera). Toronto, ON: University of Toronto Press; 1977:1-401.

38. Hiley PD: The identification of British limnephilid larvae (Trichoptera). Syst Entomol 1976, 1:147-167.

39. Wallace ID, Wallace B, Philipson GN: Keys to the case-bearing caddis larvae of Britain and Ireland. Freshwater Biological Association Scientific Publication 2003, 61:1-259.

40. Warringer J, Graf W: Atlas of Austrian caddisfly larvae, with inclusion of adjacent areas. Vienna, Austria: Facultas Universitätsverlag; 1997.

41. Flint OS, Giberson DJ: Salt marsh caddisflies: discovery of the larval and larval habitat of Limnephilus ademus in salt marshes in Prince Edward Island, Canada. I. In Proceedings of the 11th International Symposium on Trichoptera. Edited by Tanida K, Kanagawa RA. Kanagawa: Tokai University Press; 2005:121-130.

42. Grigorenko VN: Some taxonomical notes on the limnephiline caddisflies (Trichoptera: Limnephilidae: Limnephilinae). Nova Supplementa Entomologica 2002, 15:107-119.

43. Malicky H: Ein kommentiertes Verzeichnis der Köcherfliegen (Trichoptera) Europas und des Mediterrangebietes. Linzer Biologische Beiträge 2005, 37:533-596

44. Vshivkova TS, Morse JC, Ruiter D: Phylogeny of Limnephilidae and composition of the genus Limnephilus (Limnephilidae. In Proceedings of the 12th International
Symposium on Trichoptera. Edited by Bueno-Soria J, Barba-Álvarez R, Armitage BJ Columbus, OH: The Caddis Press; 2007:309-319.

45. Wiggins GB, Richardson JS: Revision of the Onocosmoecus unicolor group (Trichoptera: Limnephilidae, Dicosmoecinae). Psyche 1986, 93:187-216.

46. Wiggins GB: The caddisfly family Phryganeidae (Trichoptera). Toronto, ON: University of Toronto Press; 1998.

47. Ross HH: The caddisflies or Trichoptera of Illinois. Bulletin of the Illinois Natural History Survey 1944, 23:1-326.

48. Flint OS: Notes on some Nearctic Psychomyiidae with special reference to their larvae (Trichoptera). Proceedings of the United States National Museum 1964, 115:467-481.

49. Wiggins GB, Parker CR: Caddisflies (Trichoptera) of the Yukon, with analysis of the Beringian and Holarctic species of North America. In Insects of the Yukon. Edited by Danks HV, Downes JA. Ottawa, ON: Biological Survey of Canada (Terrestrial Arthropods); 1997:787-866.

50. Ahrens D, Monaghan MT, Vogler AP: DNA-based taxonomy for associating adults and larvae in multi-species assemblages of chafers (Coleoptera: Scarabaeidae). Mol Phylogenet Evol 2007, 44:436-449.

51. Ekrem T, Willassen E, Stur E: A comprehensive DNA sequence library is essential for identification with DNA barcodes. Mol Phylogenet Evol 2007, 43:530-542.

52. Richard B, Decaëns T, Rougerie R, James SW, Porco D, Hebert PDN: Re-integrating earthworm juveniles into soil biodiversity studies: species identification through DNA barcoding. Mol Ecol Resour 2010, 10:606-614

53. Webb KE, Barnes DKA, Clark MS, Bowden DA: DNA barcoding: a molecular tool to identify Antarctic marine larvae. Deep Sea Research Part II: Topical Studies in Oceanography 2006, 53:1053-1060.

54. Tang RWK, Yau C, Ng W-C: Identification of stomatopod larvae (Crustacea: Stomatopoda) from Hong Kong waters using DNA barcodes. Mol Ecol Resour 2010, 10:439-448.

55. Briski E, Cristescu ME, Bailey SA, Maclsaac HJ: Use of DNA barcoding to detect invertebrate invasive species from diapausing eggs. Biol Invasions 2011, 13:1325-1340.

56. Puillandre N, Strong EE, Bouchet P, Boisselier M-C, Couloux A, Samadi S: Identifying gastropod spawn from DNA barcodes: possible but not yet practicable. Mol Ecol Resour 2009, 9:1311-1321.

57. Ivanova NV, DeWaard JR, Hebert PDN: An inexpensive, automation-friendly protocol for recovering high-quality DNA. Molecular Ecology Notes 2006, 6:998-1002

58. Folmer O, Black M, Hoeh W, Lutz R, Vrijenhoek R: DNA primers for amplification of mitochondrial cytochrome $c$ oxidase subunit I from diverse metazoan invertebrates. Mol Mar Biol Biotechnol 1994, 3:294-299.

59. Hebert PDN, Penton EH, Burns JM, Janzen DH, Hallwachs W: Ten species in one: DNA barcoding reveals cryptic species in the neotropical skipper butterfly Astraptes fulgerator. Proc Natl Acad Sci 2004, 101:14812-14817.

60. Hajibabaei M, DeWaard JR, Ivanova NV, Ratnasingham S, Dooh RT, Kirk SL, Mackie PM, Hebert PDN: Critical factors for assembling a high volume of DNA barcodes. Philosophical Transactions of the Royal Society B: Biological Sciences 2005, 360:1959-1967.

61. Tamura K, Peterson D, Peterson N, Stecher G, Nei M, Kumar S: MEGA5: Molecular Evolutionary Genetics Analysis using Maximum Likelihood, Evolutionary Distance, and Maximum Parsimony Methods. Mol Biol Evol 2011, 28:2731-2739.

62. Saitou N, Nei M: The neighbor-joining method: a new method for reconstructing phylogenetic trees. Mol Biol Evol 1987, 4:406-425.

63. Kimura M: A simple method for estimating evolutionary rates of base substitutions through comparative studies of nucleotide sequences. J Mol Evol 1980, 16:111-120.

64. Milne MJ: The "metamorphotype method" in Trichoptera. New York Entomological Society 1938, 46:435-437.

65. Merritt RW, Cummins KW, Berg MB: An introduction to aquatic insects of North America. 4th edition. Dubuque, IA: Kendall/Hunt Publishing Company; 2008:1-1158.

doi:10.1186/1472-6785-13-5

Cite this article as: Ruiter et al:: DNA barcoding facilitates associations and diagnoses for Trichoptera larvae of the Churchill (Manitoba, Canada) area. BMC Ecology 2013 13:5. 